\title{
Intra- and Intergeneric Similarities of Ribosomal Ribonucleic Acid Cistrons of Free-Living, Nitrogen-Fixing Bacteria
}

\author{
J. DE SMEDT, M. BAUWENS, R. TYTGAT, AND J. DE LEY
}

Laboratorium voor Microbiologie en Microbiële Genetica, Faculteit der Wetenschappen, Rijksuniversiteit, B-9000 Gent, Belgium

\begin{abstract}
${ }^{14} \mathrm{C}$-labeled ribosomal ribonucleic acid (rRNA) was prepared from Azotobacter chroococcum NCIB 8002, Azotobacter paspali 8A, Azomonas agilis NCIB 8636, Azomonas insignis WR 30, Beijerinckia indica NCIB 8712, and Azospirillum brasilense ATCC 29145 . These rRNA's were hybridized under stringent conditions with filter-fixed deoxyribonucleic acid from a great variety of gram-negative bacteria. Each hybrid was described by: (i) the temperature at which $50 \%$ of the hybrid was denatured, and (ii) the percent rRNA binding (amount in micrograms of rRNA duplexed to $100 \mu \mathrm{g}$ of deoxyribonucleic acid). These data were used to construct rRNA similarity maps. The following conclusions could be drawn concerning rRNA cistron similarities. (i) Bacterial genera with free-living, aerobic, nitrogen-fixing members are very diverse and belong to different rRNA superfamilies. The present family Azotobacteriaceae is not a biological unit, and its status as a family is highly questionable. (ii) Azotobacter chroococcum, Azotobacter vinelandii, Azotobacter beijerinckii, Azotobacter paspali, Azotobacter miscel. lum, Azotobacter armeniae, and Azotobacter nigricans belong in the genus Azotobacter. Any synonymy of these names remains to be determined. Azomonas agilis, Azomonas insignis, and Azomonas macrocytogenes constitute independent branches, which are about equidistant from Azotobacter and section I of Pseudomonas as presented in Bergey's Manual of Determinative Bacteriology, 8th ed. Xanthomonas, Alteromonas vaga, and Alteromonas communis are located in the same rRNA superfamily. (iii) The genus Beijerinckia appears to be rather heterogeneous. Its closest relatives appear to be Xanthobacter autotrophicus, "Mycobacterium" flavum, "Pseudomonas" azotocolligans, "Pseudomonas" diminuta, the authentic rhodopseudomonads, and some other organisms. These organisms belong in the same rRNA superfamily as Azospirillum, Agrobacterium, Rhizobium, Acetobacter, Gluconobacter, and Zymomonas. (iv) Derxia belongs in still another rRNA superfamily, together with Chromobacterium, Janthinobacterium, the Pseudomonas acidovorans and Pseudomonas solanacearum groups, Alcaligenes, and a few other taxa. (v) The following organisms were generically misnamed: "Azomonas insignis" ATCC 12523, "Mycobacterium" flavum 301, "Pseudomonas" azotocolligans ATCC 12417, "Pseudomonas" diminuta CCEB 513, and "Rhodopseudomonas" gelatinosa (all strains examined).
\end{abstract}

Molecular biological methods, such as deoxyribonucleic acid (DNA)-DNA or DNA-ribosomal ribonucleic acid (rRNA) hybridizations, which directly compare bacterial genomes, have opened new perspectives for bacterial classification. Many bacterial genera are phylogenetically too far removed from each other to form stable DNA-DNA hybrids. DNA-DNA hybridizations are useful either within a genus, such as Agrobacterium (20), or between genera which have not diverged too much, such as in the Enterobacteriaceae (12; D. Izard, C. Ferragut, and $H$. Leclerc, in press). rRNA's are conservative molecules $(25,36,43)$. There is a good correlation between the degree of rRNA similarity and the overall phenotypic similarity of bacterial genera $(19,23)$. Similarity between rRNA cistrons appears to be a good criterion for the classification of bacteria on generic and suprageneric levels. In this paper we attempt to clarify the intra- and intergeneric relationships of several $\mathrm{N}_{2}$-fixing bacterial taxa through DNArRNA hybridizations.

Until now classification within the family Azotobacteriaceae has been based mainly on phenotypic features $(13,31)$. Only one molecular biological character, namely DNA base composition (guanine plus cytosine $[\mathrm{G}+\mathrm{C}]$ content), 
has been examined $(15,18)$. In Bergey's Manual of Determinative Bacteriology, 8th ed. (13), these characters were used to distinguish four genera in this family. The genus Azotobacter, which was established by Beijerinck (7), consists of cyst-forming free-living, aerobic, gram-negative, nitrogen-fixing bacteria with 63 to $66 \mathrm{~mol} \%$ $\mathrm{G}+\mathrm{C}$ content. Winogradsky (49) proposed including the Azotobacter species that do not form thick-walled cysts in a new genus, Azomonas; the $\mathrm{G}+\mathrm{C}$ values of members of this genus range from 53 to $59 \mathrm{~mol} \%$. Starkey and De (41) isolated from Indian rice field soils a nitrogen-fixing organism which they named Azotobacter indicum. Because of its morphological and physiological differences from other Azotobacter species, Derx (21) proposed including this species in a new genus, Beijerinckia; its $\mathrm{G}+\mathrm{C}$ content ranges from 55 to $61 \mathrm{~mol} \%$. The genus Derxia was proposed by Jensen et al. (32) for the nitrogenfixing organism they isolated from West Bengal soil and which appeared different in many features from all previously known nitrogen-fixing strains. They included it in the Azotobacteriaceae because of its capacity to fix large amounts of nitrogen. Its $\mathrm{G}+\mathrm{C}$ content ranges from 69 to $72 \mathrm{~mol} \%$. We performed DNA-rRNA hybridizations between labeled reference rRNA's from Azotobacter chroococcum, Azotobacter paspali, Azomonas agilis, Azomonas insignis, and Beijerinckia indica strains and the DNA of a great variety of bacteria to measure the similarity of their rRNA cistrons and to establish the degree of heterogeneity within the family Azotobacter. iaceae.

We also performed hybridizations with reference rRNA from Azospirillum brasilense. Azospirilla have been isolated from the rhizospheres of a variety of grasses, legumes, and grain crops and from soils in tropical and temperate regions; they attracted special attention because of their ability to fix nitrogen (24). The name Azospiril. lum was recently proposed by Tarrand et al. (44). The genus contains two species, Azospirillum lipoferum and Azospirillum brasilense. We included the type strain (ATCC 29145) of Azospirillum brasilense and a reference strain (SpBr17) of Azospirillum lipoferum in the present study in order to determine the taxonomic position of Azospirillum.

We also examined some other free-living, $\mathbf{N}_{2^{-}}$ fixing bacteria, such as Xanthobacter autotrophicus, "Mycobacterium". flavum, and some rhodopseudomonads.

\section{MATERIALS AND METHODS}

Bacterial strains and growth conditions. The bacterial strains used in this study are listed in Table 1. Bacteriological purity of the cultures was tested by plating and by microscopic examination of living and Gram-stained cells. Mass cultures were grown in Roux flasks on media described previously (23). On a solid medium, Azotobacter chroococcum NCIB 8002 and NCIB 8003 and Derxia gummosa NCIB 9064 produced too much slime, thus preventing harvesting of the cells. These two organisms were grown in liquid culture in broad-bottomed Erlenmeyer flasks; shaking provided good aeration. The Xanthobacter autotrophicus and "Mycobacterium" flavum strains were grown in the laboratory of H. G. Schlegel. We received them as freeze-dried cell powders.

Preparation of high-molecular-weight DNA. DNA samples were prepared by the method described by Marmur (35). They were purified by $\mathrm{CsCl}$ gradient centrifugation, denatured, and fixed on cellulose nitrate membrane filters as described previously $(17,23)$.

Preparation of $\left[{ }^{14} \mathrm{C}\right]$ rRNA. Radioactively labeled rRNA was prepared as described previously $(17,23)$, using $\left[2-{ }^{14} \mathrm{C}\right]$ uracil as precursor. The specific activities of these rRNA's were as follows: 9,898 and $9,997 \mathrm{cpm} /$ $\mu \mathrm{g}$ for the 23S and 16S fractions of Azotobacter chroococcum NCIB 8002, respectively; 13,646 and 14,336 $\mathrm{cpm} / \mu \mathrm{g}$ for the 23S and 16S fractions of Azotobacter paspali $8 \mathrm{~A}$, respectively; 14,989 and $15,698 \mathrm{cpm} / \mu \mathrm{g}$ for the 23S and 16S fractions of Azomonas agilis NCIB 8636 , respectively; and 6,704 and $6,398 \mathrm{cpm} / \mu \mathrm{g}$ for the 23S and 16S fractions of Azomonas insignis WR 30 , respectively. Beijerinckia indica NCIB 8712 and Azospirillum brasilense ATCC 29145 did not incorporate $\left[2-{ }^{14} \mathrm{C}\right]$ uracil. With $\left[6-{ }^{14} \mathrm{C}\right]$ orotate as a precursor for labeling, the rRNA of $B$. indica NCIB 8712 had specific activities of 1,015 and $959 \mathrm{cpm} / \mu \mathrm{g}$ for the $23 \mathrm{~S}$ and $16 \mathrm{~S}$ fractions, respectively, whereas the rRNA of Azospirillum brasilense ATCC 29145 had specific activities of 2,267 and $2,300 \mathrm{cpm} / \mu \mathrm{g}$ for the $23 \mathrm{~S}$ and $16 \mathrm{~S}$ fractions. B. indica NCIB 8712 and Azospirillum ATCC 29145 were selected because they are the type strains of their respective species $(13,44)$, and the four other strains were selected because they were among the oldest available in their taxa. Azotobacter chroococcum NCIB 8002 appears to be the original Azomonas strain 1 of Winogradsky (9). Azotobacter paspali $8 \mathrm{~A}$, kindly provided by J. Döbereiner, was one of the original strains of Döbereiner. Azomonas agilis NCIB 8636 is one of the strains of J. Smit (9). Azomonas insignis WR 30 was strain 8 of V. Jensen and was isolated in 1954 (J. P. Thompson, personal communication).

Hybridizations. Hybridizations, ribonuclease treatments, and thermal stability measurements of the hybrids were performed as described previously (17, 23). Hybridizations were carried out in $2 \times$ sodium saline citrate buffer ( $1 \times$ sodium saline citrate buffer is $0.15 \mathrm{NaCl}$ plus $0.015 \mathrm{M}$ sodium citrate), $\mathrm{pH} 7.0$ containing $20 \%$ formamide at the stringent temperature of $50^{\circ} \mathrm{C}$ (17). For the experiments with the rRNA of $B$. indica NCIB 8712 , a slight modification was needed because of the low specific activity; the thermal stability was measured by increasing temperature steps of $10^{\circ} \mathrm{C}$ instead of $5^{\circ} \mathrm{C}$. By counting each sample for $100 \mathrm{~min}$, the results were well within the limits of sensitivity. We used 23S labeled rRNA in all hybridizations except those with $B$. indica, where we had to use $16 \mathrm{~S}$. 
TABLE 1. List of organisms used, their strain numbers, DNA base compositions and properties of the DNA. $r R N A$ hybrids with three ${ }^{14} \mathrm{C}$-labeled rRNA references

\begin{tabular}{|c|c|c|c|c|c|c|c|c|c|}
\hline \multirow{3}{*}{$\begin{array}{l}\text { Sequence } \\
\text { no. in } \\
\text { Fig. } 2 \\
\text { and } 3\end{array}$} & \multirow{3}{*}{$\begin{array}{c}\text { Species used for DNA } \\
\text { prepn }\end{array}$} & \multirow{3}{*}{$\begin{array}{l}\text { Strain } \\
\text { no. }\end{array}$} & \multirow{3}{*}{$\begin{array}{c}\mathrm{G}+\mathrm{C} \\
\text { content } \\
(\mathrm{mol} \%)^{a}\end{array}$} & \multicolumn{6}{|c|}{ Hybridization with $\left[{ }^{14} \mathrm{C}\right] \mathrm{rRNA}$ from: } \\
\hline & & & & \multicolumn{2}{|c|}{$\begin{array}{c}\text { Azotobacter } \\
\text { chroococcum } \\
\text { NCIB } 8002\end{array}$} & \multicolumn{2}{|c|}{$\begin{array}{c}\text { B. indica NCIB } \\
8712\end{array}$} & \multicolumn{2}{|c|}{$\begin{array}{c}\text { Azospirillum } \\
\text { brasilense ATCC } \\
29145\end{array}$} \\
\hline & & & & $\begin{array}{l}T_{m(e)} \\
\left({ }^{\circ} \mathrm{C}\right)\end{array}$ & $\begin{array}{c}\text { rRNA } \\
\text { binding } \\
(\%)\end{array}$ & $\begin{array}{l}T_{m(e)} \\
\left({ }^{\circ} \mathrm{C}\right)\end{array}$ & $\begin{array}{c}\text { rRNA } \\
\text { binding } \\
(96)\end{array}$ & $\begin{array}{l}T_{m(e)} \\
\left({ }^{\circ} \mathrm{C}\right)\end{array}$ & $\begin{array}{c}\text { rRNA } \\
\text { binding } \\
(\%)\end{array}$ \\
\hline 1 & Azotobacter chroococcum & NCIB 8002 & (65.9) & 81 & 0.167 & & & & \\
\hline 2 & Azotobacter chroococcum & NCIB 8003 & 66.2 & 81 & 0.160 & & & & \\
\hline 3 & Azotobacter chroococcum & NCIB 8515 & 67.5 & 81 & 0.166 & & & & \\
\hline 4 & Azotobacter chroococcum & NCIB 9125 & 66.0 & 81 & 0.140 & & & & \\
\hline 5 & Azotobacter chroococcum & DSM 281 & 66.3 & 81 & 0.166 & & & & \\
\hline 6 & Azotobacter chroococcum & DSM 328 & 66.7 & 81 & 0.150 & & & & \\
\hline 7 & Azotobacter chroococcum & DSM 368 & $(66.3)$ & 80.5 & 0.163 & & & & \\
\hline 8 & Azotobacter chroococcum & DSM 369 & $(66.1)$ & 81 & 0.147 & & & & \\
\hline 9 & Azotobacter chroococcum & DSM 374 & 65.8 & 81 & 0.152 & & & & \\
\hline 10 & Azotobacter chroococcum & DSM 377 & 66.4 & 80.5 & 0.133 & 61 & 0.069 & & \\
\hline 11 & Azotobacter beijerinckii & NCIB 9067 & 66.2 & 79.5 & 0.143 & & & & \\
\hline 12 & Azotobacter beijerinckii & NCIB 9126 & (66.3) & 80.5 & 0.140 & & & & \\
\hline 13 & Azotobacter beijerinckii & DSM 282 & 66.0 & 80 & 0.161 & & & & \\
\hline 14 & Azotobacter beijerinckii & DSM 367 & 66.2 & 80 & 0.173 & & & & \\
\hline 15 & Azotobacter beijerinckii & DSM 373 & $(65.5)$ & 80 & 0.141 & 60.5 & 0.060 & & \\
\hline 16 & Azotobacter beijerinckii & DSM 378 & 66.2 & 80 & 0.177 & & & & \\
\hline 17 & Azotobacter beijerinckii & DSM 381 & (65.6) & 80 & 0.133 & & & & \\
\hline 18 & Azotobacter vinelandii & NCIB 8789 & 66.5 & 78 & 0.167 & & & & \\
\hline 19 & Azotobacter vinelandii & NCIB 9068 & (65.6) & 77.5 & 0.145 & & & & \\
\hline 20 & Azotobacter vinelandii & NCIB 8660 & 65.0 & 79 & 0.147 & & & & \\
\hline 21 & Azotobacter vinelandii & DSM 85 & $(65.0)$ & 78.5 & 0.159 & 59 & 0.087 & & \\
\hline 22 & Azotobacter vinelandii & DSM 86 & (66.3) & 78.5 & 0.140 & & & & \\
\hline 23 & Azotobacter vinelandii & DSM 366 & 64.9 & 78.5 & 0.163 & & & & \\
\hline 24 & Azotobacter vinelandii & DSM 382 & (66.3) & 79 & 0.130 & & & & \\
\hline 25 & Azotobacter vinelandii & DSM 389 & (66.8) & 79 & 0.133 & & & & \\
\hline 26 & Azotobacter vinelandii & $\mathrm{C} 2 \mathrm{sm}$ & 65.8 & 78 & 0.171 & & & & \\
\hline 27 & Azotobacter miscellum & ATCC 17962 & 65.6 & 78.5 & 0.130 & & & & \\
\hline 28 & Azotobacter paspali & DSM 88 & $(63.0)$ & 77.5 & 0.165 & & & & \\
\hline 29 & Azotobacter paspali & DSM 376 & (63.4) & 77.5 & 0.150 & & & & \\
\hline 30 & Azotobacter paspali & DSM 383 & $(64.6)$ & 78.5 & 0.144 & & & & \\
\hline 31 & Azotobacter paspali & DSM 388 & $(63.0)$ & 78 & 0.153 & & & & \\
\hline 32 & Azotobacter paspali & DSM 391 & 63.9 & 78.5 & 0.139 & & & & \\
\hline 33 & Azotobacter paspali & DSM 400 & 63.8 & 77.5 & 0.164 & 59 & 0.052 & & \\
\hline 34 & Azotobacter paspali & Döbereiner 8A & 63.2 & 78 & 0.171 & & & & \\
\hline 35 & Azotobacter paspali & Döbereiner 15B & 63.3 & 78 & 0.160 & & & & \\
\hline 36 & Azotobacter paspali & Döbereiner 22B & 63.7 & 78 & 0.151 & & & & \\
\hline 37 & Azotobacter paspali & Döbereiner 23A & 64.6 & 78.5 & 0.166 & & & & \\
\hline 38 & Azotobacter nigricans & WR 128 & 64.5 & 79 & 0.161 & & & & \\
\hline 39 & Azotobacter armeniae & WR 136 & 65.0 & 80 & 0.171 & & & & \\
\hline 40 & Azotobacter armeniae & WR 138 & 63.5 & 79 & 0.153 & & & & \\
\hline 41 & Azotobacter armeniae & WR 139 & 64.7 & 80 & 0.167 & & & & \\
\hline 42 & Azomonas agilis & WR 54 & 52.9 & 77 & 0.106 & & & & \\
\hline 43 & Azomonas agilis & NCIB 8636 & 52.6 & 76 & 0.088 & & & & \\
\hline 44 & Azomonas agilis & NCIB 8637 & 53.2 & 77 & 0.087 & & & & \\
\hline 45 & Azomonas agilis & NCIB 8638 & $(53.2)$ & 77 & 0.088 & & & & \\
\hline 46 & Azomonas agilis & DSM 89 & 52.0 & 76 & 0.092 & 62 & 0.066 & & \\
\hline 47 & Azomonas agilis & DSM 375 & (51.9) & 77 & 0.100 & & & & \\
\hline 48 & Azomonas agilis & $\mathrm{SS}_{4}$ & 52.8 & 76 & 0.077 & & & & \\
\hline 49 & $\begin{array}{l}\text { Azomonas macrocyto- } \\
\text { genes }\end{array}$ & NCIB 8700 & $(59.0)$ & 76.5 & 0.130 & 58 & 0.060 & & \\
\hline 50 & $\begin{array}{l}\text { Azomonas macrocyto- } \\
\text { genes }\end{array}$ & NCIB 8701 & $(59.2)$ & 76 & 0.129 & & & & \\
\hline 51 & $\begin{array}{l}\text { Azomonas macrocyto- } \\
\text { genes }\end{array}$ & NCIB 8702 & $(59.0)$ & 76 & 0.136 & & & & \\
\hline 52 & $\begin{array}{l}\text { Azomonas macrocyto- } \\
\text { genes }\end{array}$ & NCIB 9128 & 58.6 & 77 & 0.118 & & & & \\
\hline 53 & $\begin{array}{l}\text { Azomonas macrocyto- } \\
\text { genes }\end{array}$ & NCIB 9129 & 58.2 & 76 & 0.118 & & & & \\
\hline 54 & "Azomonas insignis" & ATCC 12523 & 43.4 & 68 & 0.139 & & & & \\
\hline 55 & Azomonas insignis & Tchan C & 55.1 & 76 & 0.115 & & & & \\
\hline
\end{tabular}


TABLE 1 (continued)

\begin{tabular}{|c|c|c|c|c|c|c|c|c|c|}
\hline \multirow{3}{*}{$\begin{array}{l}\text { Sequence } \\
\text { no. in } \\
\text { Fig. } 2 \\
\text { and } 3\end{array}$} & \multirow{3}{*}{$\begin{array}{c}\text { Species used for DNA } \\
\text { prepn }\end{array}$} & \multirow{3}{*}{$\begin{array}{l}\text { Strain } \\
\text { no. }\end{array}$} & \multirow{3}{*}{$\begin{array}{c}\mathrm{G}+\mathrm{C} \\
\text { content } \\
(\mathrm{mol} \%)^{a}\end{array}$} & \multicolumn{6}{|c|}{ Hybridization with $\left[{ }^{14} \mathrm{C}\right] \mathrm{rRNA}$ from: } \\
\hline & & & & \multicolumn{2}{|c|}{$\begin{array}{c}\text { Azotobacter } \\
\text { chroococcum } \\
\text { NCIB } 8002\end{array}$} & \multicolumn{2}{|c|}{$\begin{array}{c}\text { B. indica NCIB } \\
8712\end{array}$} & \multicolumn{2}{|c|}{$\begin{array}{c}\text { Azospirillum } \\
\text { brasilense ATCC } \\
29145\end{array}$} \\
\hline & & & & $\begin{array}{l}T_{m(e)} \\
\left({ }^{\circ} \mathrm{C}\right)\end{array}$ & $\begin{array}{c}\text { rRNA } \\
\text { binding } \\
(\%)\end{array}$ & $\begin{array}{l}T_{n(e)} \\
\left({ }^{\circ} \mathrm{C}\right)\end{array}$ & $\begin{array}{c}\text { rRNA } \\
\text { binding } \\
(\%)\end{array}$ & $\begin{array}{l}T_{n(e)} \\
\left({ }^{\circ} \mathrm{C}\right)\end{array}$ & $\begin{array}{c}\text { rRNA } \\
\text { binding } \\
(\%)\end{array}$ \\
\hline 56 & Azomonas insignis & Tchan D & 55.6 & 76.5 & 0.108 & 62.5 & 0.054 & & \\
\hline 57 & Azomonas insignis & WR 12 & $(58.0)$ & 76 & 0.107 & & & & \\
\hline 58 & Azomonas insignis & WR 29 & $(57.6)$ & 76.5 & 0.117 & & & & \\
\hline 59 & Azomonas insignis & WR 30 & 57.5 & 77 & 0.111 & & & & \\
\hline 60 & Azomonas insignis & WR 31 & 57.1 & 77 & 0.121 & & & & \\
\hline 61 & Azomonas insignis & WR 56 & (57.5) & 76.5 & 0.114 & & & & \\
\hline 62 & Azomonas insignis & WR 59 & 57.8 & 77 & 0.134 & & & & \\
\hline 63 & Azomonas insignis & WR 60 & $(57.5)$ & 77 & 0.133 & & & & \\
\hline 64 & Azomonas insignis & WR 61 & (57.8) & 75.5 & 0.130 & & & & \\
\hline 65 & Azomonas insignis & WR 62 & 58.3 & 76 & 0.134 & & & & \\
\hline 66 & D. gummosa & D & 71.4 & 63 & 0.061 & & & & \\
\hline 67 & D. gummosa & D12 & 72.6 & 65.5 & 0.057 & & & & \\
\hline 68 & D. gummosa & NCIB 9064 & 69.2 & 63.5 & 0.051 & 55 & 0.028 & & \\
\hline 69 & B. indica. & NCIB 8712 & 56.4 & 61.5 & 0.064 & 78 & 0.520 & & \\
\hline 70 & B. indica & NCIB 8005 & 58.2 & & & 78 & 0.281 & & \\
\hline 71 & B. indica & NCIB 8597 & 56.3 & & & 77 & 0.267 & & \\
\hline 72 & $B$. indica & LMD 38.7 & 57.6 & & & 78 & 0.333 & & \\
\hline 73 & B. indica & (Hilger) & 57.4 & 59 & 0.051 & 77.5 & 0.292 & & \\
\hline 74 & B. fluminensis & (Hilger) & 56.2 & 60 & 0.067 & 75.5 & 0.324 & & \\
\hline 75 & B. derxii & Tchan Q 13 & 58.5 & & & 75.5 & 0.286 & & \\
\hline 76 & B. lacticogenes & NCIB 8846 & 58.5 & 60 & 0.041 & 75.5 & 0.301 & 69 & 0.047 \\
\hline 77 & B. mobilis & LMD 50.27 & 57.3 & & & 75 & 0.137 & & \\
\hline 78 & $\begin{array}{l}\text { Xanthobacter autotrophi- } \\
\text { cus }\end{array}$ & Schlegel 7C & 67.3 & 59 & 0.034 & 69.5 & 0.048 & 68.5 & 0.036 \\
\hline 79 & $\begin{array}{l}\text { Xanthobacter autotrophi- } \\
\text { cus }\end{array}$ & Schlegel GZ29 & 67.4 & & & 71.5 & 0.044 & & \\
\hline 80 & $\begin{array}{l}\text { Xanthobacter autotrophi- } \\
\text { cus }\end{array}$ & Schlegel JW50 & $(67.1)$ & & & 72 & 0.042 & 67 & 0.033 \\
\hline 81 & $\begin{array}{l}\text { Xanthobacter autotrophi- } \\
\text { cus }\end{array}$ & Schlegel JW33 & 66.8 & 60.5 & 0.028 & 70.5 & 0.043 & & \\
\hline 82 & $\begin{array}{l}\text { Xanthobacter autotrophi- } \\
\text { cus }\end{array}$ & Schlegel JW42 & 64.9 & 59.5 & 0.029 & 70 & 0.039 & & \\
\hline 83 & "Mycobacterium" flavum & 301 & 68.1 & & & 71 & 0.039 & 69 & 0.021 \\
\hline 84 & Azospirillum brasilense & ATCC 29145 & 67.5 & & & 68 & 0.121 & 82.5 & 0.158 \\
\hline 85 & Azospirillum brasilense & LMD 50.39 & 64.6 & & & 68 & 0.131 & 82 & 0.169 \\
\hline 86 & Azospirillum brasilense & Vlassak S11 & 68.4 & 63 & 0.140 & 68 & 0.136 & 82.5 & 0.165 \\
\hline 87 & Azospirillum brasilense & Vlassak S19 & 68.4 & 63 & 0.142 & 66.5 & 0.120 & 82 & 0.154 \\
\hline 88 & Azospirillum brasilense & Vlassak Si97 & 66.0 & & & 67 & 0.094 & 82 & 0.107 \\
\hline 89 & Azospirillum brasilense & Vlassak M4 & $(68.2)$ & & & 68 & 0.089 & 82.5 & 0.094 \\
\hline 90 & Azospirillum brasilense & Vlassak S631 & (67.9) & & & & & 82.5 & 0.161 \\
\hline 91 & Azospirillum brasilense & Vlassak T2W & (67.9) & & & & & 82.5 & 0.144 \\
\hline 92 & Azospirillum brasilense & Vlassak T2R & $(68.2)$ & & & & & 82.5 & 0.157 \\
\hline 93 & Azospirillum brasilense & Vlassak Sgl & $(67.7)$ & & & & & 80 & 0.118 \\
\hline 94 & Azospirillum brasilense & Vlassak R1 & (68.4) & & & & & 82.5 & 0.156 \\
\hline 95 & Azospirillum lipoferum & $\begin{array}{l}\text { Döbereiner Sp } \\
\mathrm{Br} 17\end{array}$ & 69.0 & & & & & 82 & 0.125 \\
\hline 96 & Azospirillum lipoferum & $\begin{array}{l}\text { Döbereiner } \mathrm{RG} \\
18 \mathrm{c}\end{array}$ & (68.7) & & & & & 82.5 & 0.173 \\
\hline 97 & R. palustris & ATCC 17001 & 67.2 & & & 72 & 0.042 & & \\
\hline 98 & R. capsulata & ATCC 11166 & 65.2 & & & 69 & 0.072 & & \\
\hline 99 & $R$. sphaeroides & ATCC 17023 & 68.4 & & & 69 & 0.048 & & \\
\hline 100 & R. gelatinosa & ATCC 17011 & 70.1 & & & 59 & 0.032 & & \\
\hline 101 & R. gelatinosa & Pfennig 2150 & 71.8 & & & 57 & 0.032 & & \\
\hline 102 & R. gelatinosa & Pfennig 2850 & 71.8 & & & 57.5 & 0.032 & & \\
\hline 103 & R. gelatinosa & Pfennig Dr2 & 71.3 & & & 58 & 0.031 & & \\
\hline 104 & R. acidophila & ATCC 25092 & 64.9 & & & 68 & 0.069 & & \\
\hline 106 & Pseudomonas fluorescens & ATCC 13525 & 60.2 & 76.5 & 0.117 & & & & \\
\hline 107 & Pseudomonas fluorescens & ATCC 17571 & & 77.5 & 0.109 & & & & \\
\hline 108 & Pseudomonas putida & ATCC 12633 & 62.3 & 76 & 0.099 & & & & \\
\hline 109 & Pseudomonas aeruginosa & CCEB 481 & 66.8 & 77 & 0.094 & & & & \\
\hline 110 & Pseudomonas synxantha & NCIB 8178 & 60.4 & 76 & 0.097 & & & & \\
\hline
\end{tabular}




\begin{tabular}{|c|c|c|c|c|c|c|c|c|c|}
\hline \multirow{3}{*}{$\begin{array}{l}\text { Sequence } \\
\text { no. in } \\
\text { Fig. } 2 \\
\text { and } 3\end{array}$} & \multirow{3}{*}{$\begin{array}{l}\text { Species used for DNA } \\
\text { prepn }\end{array}$} & \multirow{3}{*}{$\begin{array}{l}\text { Strain } \\
\text { no. }\end{array}$} & \multirow{3}{*}{$\begin{array}{c}\mathrm{G}+\mathrm{C} \\
\text { content } \\
(\mathrm{mol} \%)^{n}\end{array}$} & \multicolumn{6}{|c|}{ Hybridization with $\left[{ }^{14} \mathrm{C}\right] \mathrm{RRNA}$ from: } \\
\hline & & & & \multicolumn{2}{|c|}{$\begin{array}{c}\text { Azotobacter } \\
\text { chroococcum } \\
\text { NCIB } 8002\end{array}$} & \multicolumn{2}{|c|}{$\begin{array}{c}\text { B. indica NCIB } \\
8712\end{array}$} & \multicolumn{2}{|c|}{$\begin{array}{c}\text { Azospirillum } \\
\text { brasilense ATCC } \\
29145\end{array}$} \\
\hline & & & & $\begin{array}{l}T_{m(e)} \\
\left({ }^{\circ} \mathrm{C}\right)\end{array}$ & $\begin{array}{c}\text { rRNA } \\
\text { binding } \\
(\%)\end{array}$ & $\begin{array}{l}T_{m(e)} \\
\left({ }^{\circ} \mathrm{C}\right)\end{array}$ & $\begin{array}{c}\text { rRNA } \\
\text { binding } \\
(\$ \%)\end{array}$ & $\begin{array}{l}T_{m(e)} \\
\left({ }^{\circ} \mathrm{C}\right)\end{array}$ & $\begin{array}{c}\text { rRNA } \\
\text { binding } \\
(\%)\end{array}$ \\
\hline 111 & Pseudomonas oleovorans & NCTC 10692 & (63.5) & 77 & 0.111 & & & & \\
\hline 112 & Pseudomonas stutzeri & NCTC 10475 & 64.5 & 77 & 0.121 & & & & \\
\hline 113 & Pseudomonas mucidolens & NCTC 8068 & 61.0 & 76 & 0.099 & & & & \\
\hline 114 & $\begin{array}{l}\text { Pseudomonas acidovor- } \\
\text { ans }\end{array}$ & ATCC 15668 & 66.8 & 64.5 & 0.099 & & & & \\
\hline 115 & Pseudomonas desmolytica & ATCC 15005 & 68.5 & 65 & 0.093 & & & & \\
\hline 116 & $\begin{array}{l}\text { Pseudomonas indoloxi- } \\
\text { dans }\end{array}$ & ATCC $9355 t_{1}$ & 66.4 & 64 & 0.095 & & & & \\
\hline 117 & $\begin{array}{l}\text { Pseudomonas solana- } \\
\text { cearum }\end{array}$ & NCPPB 215 & $(66.9)$ & 62.5 & 0.084 & & & & \\
\hline 118 & $\begin{array}{l}\text { Pseudomonas solana- } \\
\text { cearum }\end{array}$ & NCPPB 253 & $(66.8)$ & 64 & 0.086 & & & & \\
\hline 119 & $\begin{array}{l}\text { "Pseudomonas" azotocol- } \\
\text { ligans }\end{array}$ & ATCC 12417 & 65.6 & 60.5 & 0.044 & 70 & 0.040 & & \\
\hline 120 & "Pseudomonas" diminuta & CCEB 513 & 67.3 & & & 69 & 0.060 & & \\
\hline 121 & Xanthomonas taraxaci & ICPB T11 & 64.3 & 67 & 0.062 & & & & \\
\hline 122 & $\begin{array}{l}\text { Xanthomonas poinsettiae- } \\
\text { color }\end{array}$ & ICPB P137 & 66.0 & 67 & 0.064 & & & & \\
\hline 123 & Xanthomonas alfalfae & ICPB A121 & 67.3 & 66.5 & 0.066 & & & & \\
\hline 124 & Xanthomonas fragariae & NCPPB 1822 & 63.3 & 66.5 & 0.063 & & & & \\
\hline 125 & "Xanthomonas" ampelina & P7 & & 62 & 0.072 & & & & \\
\hline 126 & "Xanthomonas" ampelina & $\mathrm{C} 13$ & 68.2 & 60.5 & 0.077 & & & & \\
\hline 127 & "Xanthomonas" ampelina & $2 \mathrm{C}$ & 68.5 & 61 & 0.077 & & & & \\
\hline 128 & Escherichia coli & B & 52.2 & 69 & 0.118 & & & & \\
\hline 129 & Serratia marcescens & NCTC 2847 & 55.3 & 68 & 0.137 & & & & \\
\hline 130 & Klebsiella rubiacearum & ATCC 15574 & 59.3 & 68 & 0.122 & & & & \\
\hline 131 & Enterobacter aerogenes & NCTC 10006 & 53.8 & 67.5 & 0.150 & & & & \\
\hline 132 & Vibrio sp. (noncholera) & E509 & 49.0 & 68.5 & 0.241 & & & & \\
\hline 133 & Vibrio anguillarum & ATCC 14181 & 44.2 & 68 & 0.198 & & & & \\
\hline 134 & Vibrio fischeri & NCMB 1281 & 38.5 & 66 & 0.225 & & & & \\
\hline 135 & Vibrio marinus & NCMB 1143 & 42.3 & 66 & 0.241 & & & & \\
\hline 136 & Alteromonas haloplanktis & ATCC 19855 & 41.8 & 67 & 0.194 & & & & \\
\hline 137 & Alteromonas haloplanktis & ATCC 27127 & 42.6 & 67 & 0.161 & & & & \\
\hline 138 & Alteromonas haloplanktis & ATCC 19648 & 42.6 & 68.5 & 0.208 & & & & \\
\hline 139 & Alteromonas macleodii & ATCC 27126 & 45.6 & 68 & 0.123 & & & & \\
\hline 140 & Alteromonas vaga & ATCC 27119 & 47.7 & 71.5 & 0.216 & & & & \\
\hline 141 & Alteromonas communis & ATCC 27118 & 47.0 & 72 & 0.234 & & & & \\
\hline 142 & $\begin{array}{l}\text { Janthinobacterium livi- } \\
\text { dum }\end{array}$ & NCTC 9796 & 65.5 & 64 & 0.138 & & & & \\
\hline 143 & $\begin{array}{l}\text { Janthinobacterium livi- } \\
\text { dum }\end{array}$ & ATCC 14487 & & 63 & 0.155 & & & & \\
\hline 144 & $\begin{array}{l}\text { Janthinobacterium livi- } \\
\text { dum }\end{array}$ & MRC RU & 65.5 & 63.5 & 0.120 & & & & \\
\hline 145 & $\begin{array}{l}\text { Chromobacterium viola- } \\
\text { ceum }\end{array}$ & NCTC 9757 & 67.2 & 64.5 & 0.171 & & & & \\
\hline 146 & $\begin{array}{l}\text { Chromobacterium viola- } \\
\text { ceum }\end{array}$ & NCTC 9371 & 66.1 & 65.5 & 0.156 & & & & \\
\hline 147 & $\begin{array}{l}\text { "Chromobacterium" } \\
\text { maris-mortui }\end{array}$ & ATCC 17056 & 61.8 & 71.5 & 0.185 & & & & \\
\hline 148 & Alcaligenes faecalis & NCIB 8156 & 57.5 & 64 & 0.077 & & & & \\
\hline 149 & Alcaligenes faecalis & ATCC 19018 & 58.9 & 64.5 & 0.086 & & & & \\
\hline 150 & Alcaligenes odorans & CCEB 554 & 56.6 & 64 & 0.091 & & & & \\
\hline 151 & Celluibrio vulgaris & NCIB 8633 & 51.5 & 68 & 0.069 & & & & \\
\hline 152 & Microcyclus aquaticus & NCIB 9271 & & 59 & 0.042 & & & & \\
\hline 153 & Acetobacter pasteurianus & $23 \mathrm{~kJ}^{+}$ & 55.4 & & & 66 & 0.092 & 68.5 & 0.121 \\
\hline 154 & Acetobacter pasteurianus & NCIB 8090 & 58.0 & 60.5 & 0.073 & & & & \\
\hline 155 & Acetobacter aceti & NCIB 8554 & 55.9 & 60.5 & 0.080 & & & & \\
\hline 156 & Acetobacter aceti & NCIB 4940 & $(55.7)$ & & & 66 & 0.102 & & \\
\hline 157 & Gluconobacter oxydans & NCIB 8036 & 62.0 & & & 66 & 0.115 & 69 & 0.121 \\
\hline 158 & Gluconobacter oxydans & 116 & 60.6 & & & 66 & 0.093 & & \\
\hline
\end{tabular}


TABLE 1 (continued)

\begin{tabular}{|c|c|c|c|c|c|c|c|c|c|}
\hline \multirow{3}{*}{$\begin{array}{c}\text { Sequence } \\
\text { no. in } \\
\text { Fig. } 2 \\
\text { and } 3\end{array}$} & \multirow{3}{*}{$\begin{array}{l}\text { Species used for DNA } \\
\text { prepn }\end{array}$} & \multirow{3}{*}{$\begin{array}{c}\text { Strain } \\
\text { no. }\end{array}$} & \multirow{3}{*}{$\begin{array}{c}\mathrm{G}+\mathrm{C} \\
\text { content } \\
\text { (mol\%) }\end{array}$} & \multicolumn{6}{|c|}{ Hybridization with $\left[{ }^{14} \mathrm{C}\right] \mathrm{rRNA}$ from: } \\
\hline & & & & \multicolumn{2}{|c|}{$\begin{array}{c}\text { Azotobacter } \\
\text { chroococcum } \\
\text { NCIB } 8002\end{array}$} & \multicolumn{2}{|c|}{$\begin{array}{l}\text { B. indica NCIB } \\
8712\end{array}$} & \multicolumn{2}{|c|}{$\begin{array}{c}\text { Azospirillum } \\
\text { brasilense ATCC } \\
29145\end{array}$} \\
\hline & & & & $\begin{array}{l}T_{m(\text { le })} \\
\left({ }^{\circ} \mathrm{C}\right)\end{array}$ & $\begin{array}{c}\text { rRNA } \\
\text { binding } \\
\text { (\%) }\end{array}$ & $\begin{array}{l}T_{m(e)} \\
\left({ }^{\circ} \mathrm{C}\right)\end{array}$ & $\begin{array}{c}\text { rRNA } \\
\text { binding } \\
\text { (क) }\end{array}$ & $\begin{array}{l}T_{\text {m(e) }} \\
\left({ }^{\circ} \mathrm{C}\right)\end{array}$ & $\begin{array}{c}\text { rRNA } \\
\text { binding } \\
(\%)\end{array}$ \\
\hline 159 & $\begin{array}{l}\text { Zymomonas mobilis subsp. } \\
\text { mobilis }\end{array}$ & ATCC 29191 & 48.8 & & & 66 & 0.080 & & \\
\hline 160 & $\begin{array}{l}\text { Zymomonas mobilis subsp. } \\
\text { mobilis }\end{array}$ & B70 & & & & 66 & 0.080 & & \\
\hline 161 & $\begin{array}{l}\text { Zymomonas mobilis subsp. } \\
\text { mobilis }\end{array}$ & 5.3 & 49.3 & & & 66 & 0.070 & & \\
\hline 162 & $\begin{array}{l}\text { Zymomonas mobilis subsp. } \\
\text { mobilis }\end{array}$ & $\mathrm{CP3}$ & & & & 67 & 0.090 & & \\
\hline 163 & $\begin{array}{l}\text { Zymomonas mobilis subsp. } \\
\text { mobilis }\end{array}$ & AG11 & & & & 67 & 0.090 & & \\
\hline 164 & $\begin{array}{l}\text { Zymomonas mobilis subsp. } \\
\text { mobilis }\end{array}$ & Delft 6 & & & & 66.5 & 0.110 & & \\
\hline 165 & $\begin{array}{l}\text { Zymomonas mobilis subsp. } \\
\text { pomaceae }\end{array}$ & ATCC 29192 & 47.7 & & & 66.5 & 0.080 & & \\
\hline 166 & $\begin{array}{l}\text { Agrobacterium tumefa- } \\
\text { ciens }\end{array}$ & ICPB TT111 & 60.6 & & & 67 & 0.074 & 65 & 0.042 \\
\hline 167 & $\begin{array}{l}\text { Agrobacterium tumefa- } \\
\text { ciens }\end{array}$ & CIP B6 & 61.8 & & & 67 & 0.059 & & \\
\hline 168 & $\begin{array}{l}\text { "Agrobacterium" aggre } \\
\text { gatum }\end{array}$ & Ahrens B1 & 58.7 & & & 72 & 0.063 & & \\
\hline 169 & $\begin{array}{l}\text { "Agrobacterium" gelati- } \\
\text { novorum }\end{array}$ & Ahrens B6 & 57.6 & & & 67.5 & 0.029 & & \\
\hline 170 & "Agrobacterium" luteum & Ahrens B14 & 52.5 & & & 66 & 0.033 & & \\
\hline 171 & "Azotomonas" insolita & ATCC 12412 & 60.5 & & & 68 & 0.071 & & \\
\hline 172 & "Azotomonas" species & ATCC 12210 & $(58.0)$ & & & 67.5 & 0.058 & & \\
\hline 173 & $\begin{array}{l}\text { "Chromobacterium" fol- } \\
\text { ium }\end{array}$ & NCTC 10591 & 63.0 & & & 66.5 & 0.045 & & \\
\hline 174 & Paracoccus denitrificans & ATCC 19367 & 67.4 & & & 67 & 0.049 & 67.5 & 0.061 \\
\hline 175 & Paracoccus denitrificans & ATCC 17741 & 66.4 & & & 66 & 0.060 & & \\
\hline 176 & $\begin{array}{l}\text { S. itersonii subsp. vulga- } \\
\text { tum }\end{array}$ & NCIB 9071 & 62.3 & & & 69 & 0.088 & 72.5 & 0.111 \\
\hline 177 & S. polymorphum & NCIB 9072 & 63.7 & & & & & 71.5 & 0.075 \\
\hline
\end{tabular}

"The $\mathrm{G}+\mathrm{C}$ contents were determined in our laboratory by thermal denaturation, except for those taxa with values in parentheses, which were determined from absorbance ratios (14).

${ }^{b}$ Organisms with taxon names in quotation marks are misnamed and do not belong in that taxon.

\section{RESULTS}

Sucrose gradient centrifugation of rRNA. An example of a sucrose gradient sedimentation pattern for each of the six reference rRNA's is shown in Fig. 1. The 23S fraction of $B$. indica NCIB 8712 was much smaller than its 16 S fraction. The same kind of profile was found for Agrobacterium tumefaciens TT111 and Agrobacterium rhizogenes TR7 (23) and for Acetobacter aceti NCIB 8621 (M. Gillis and J. De Ley, manuscript in preparation). We show below that Beijerinckia appears to be a relative of these taxa.

DNA-rRNA hybridizations. The results of the hybridizations are expressed as the temperature at which $50 \%$ of a hybrid was denatured $\left(T_{m(e)}\right)$ and the percentage of rRNA binding (micrograms of ${ }^{14} \mathrm{C}$-labeled rRNA duplexed per
$100 \mu \mathrm{g}$ of filter-fixed DNA). By plotting $\left.T_{m(e)}\right)$ against percent binding, we obtained rRNA similarity maps. It has to be stressed that the percent rRNA binding is not a measure of rRNA homology, because the latter also depends on the number of rRNA cistrons per genome and the size and the state of replication of the genome (23). It has been reported previously (19, 23) that there is a good correlation between the degree of rRNA similarity, expressed as $T_{m(e)}$, and the overall phenotypic similarity of bacterial genera or subgenera. Each taxon occupies a definite area on the rRNA similarity map. The size and shape of this area depend on the phenotypic and genetic heterogeneity of the taxon when many strains are included. A few strains suffice to locate a taxon area on the map. Table 2 shows the $T_{m(e)}$ values and the percentages of rRNA binding of the reciprocal hybrids between the 

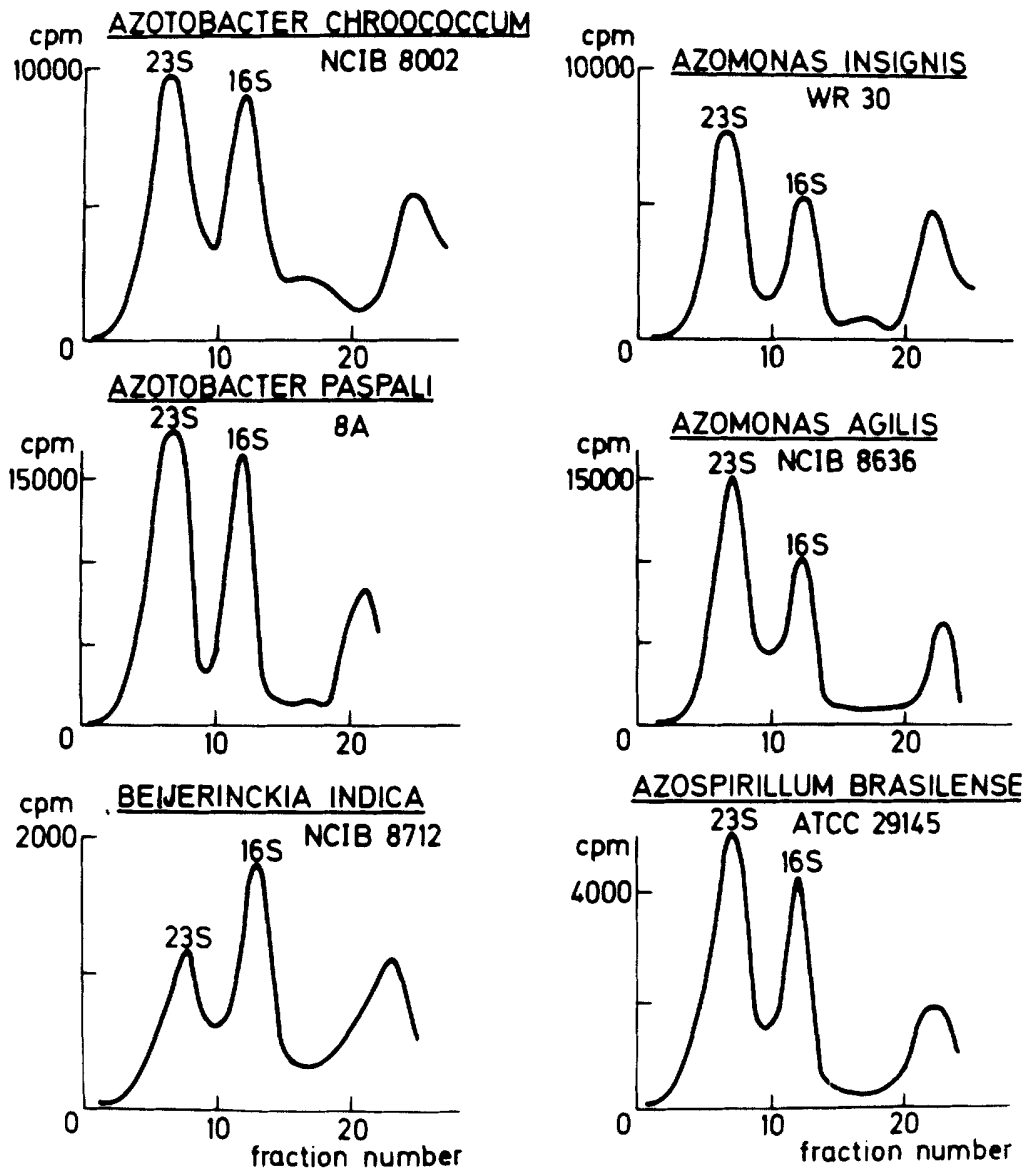

FIG. 1. Fractionation of ${ }^{14} \mathrm{C}$-labeled rRNA's on 15 to $30 \%$ linear sucrose gradients. The method used has been described previously (17).

DNAs of Azotobacter, Azomonas, Beijerinckia, and Derxia strains and ${ }^{14} \mathrm{C}$-labeled rRNA from representative strains of various other genera. $T_{m(e)}$ values of the reciprocal hybrids for each set of two strains were almost the same.

Similarity of Azotobacter rRNA cistrons. The rRNA similarity map of Azotobacter chroococcum NCIB 8002 is shown in Fig. 2. The rRNA cistrons of all Azotobacter strains were highly similar $\left(T_{m(e)}\right.$, from 77.5 to $\left.81^{\circ} \mathrm{C}\right)$. Although the differences in $T_{m(e)}$ were small, the species that produce a water-soluble fluorescent pigment (Azotobacter vinelandii and Azotobacter pas. pali, with $T_{m(e)}$ values of 77.5 to $79^{\circ} \mathrm{C}$ ) could be differentiated from the species that do not produce such a pigment (Azotobacter chroococcum, Azotobacter beijerinckii, Azotobacter nigricans, and Azotobacter armeniae, with $T_{m(e)} \mathrm{val}$ ues between 79 and $81^{\circ} \mathrm{C}$ ). This differentiation was also found with $\left[{ }^{14} \mathrm{C}\right] \mathrm{rRNA}$ from Azotobacter paspali 8A (Table 3); Azotobacter paspali and Azotobacter vinelandii strains had $T_{m(e)}$ values of 81 to $81.5^{\circ} \mathrm{C}$, whereas the remaining Azotobacter strains had $T_{m(e)}$ values ranging from 77.5 to $79^{\circ} \mathrm{C}$.

Except for Azomonas insignis ATCC 12523, the DNA-rRNA hybrids of the Azomonas strains had high $T_{m(e)}$ values $\left(75.5\right.$ to $77^{\circ} \mathrm{C}$ ). The $T_{m(e)}$ of $68^{\circ} \mathrm{C}$ for strain ATCC 12523 was far outside the range of Azomonas. We received two subcultures of this strain from the American Type Culture Collection, and both gave the same results. This strain is discussed below.

The strains belonging to Pseudomonas section I in Bergey's Manual of Determinative Bacteriology (13) grouped at a high $T_{m(e)}$ (76 to $77^{\circ} \mathrm{C}$ ). These strains were Pseudomonas fluorescens ATCC 13525, Pseudomonas fluorescens ATCC 17571, Pseudomonas putida ATCC 12633, Pseudomonas aeruginosa CCEB 481, Pseudomonas synxantha NCIB 8178, Pseudomonas oleovorans NCTC 10692, Pseudomonas stutzeri NCTC 10475, and Pseudomonas mucidolens NCTC 8068. The close relationship of 


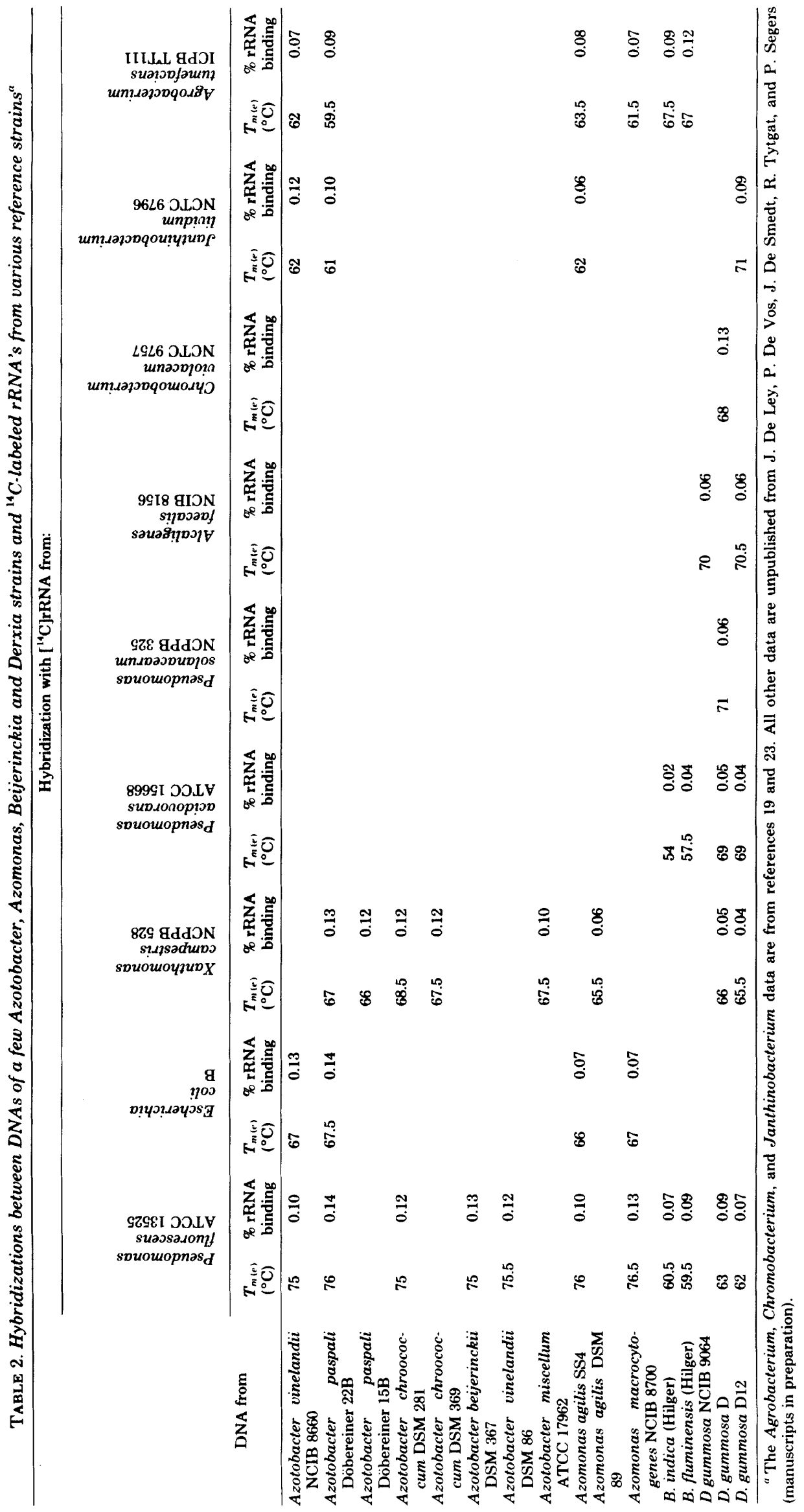




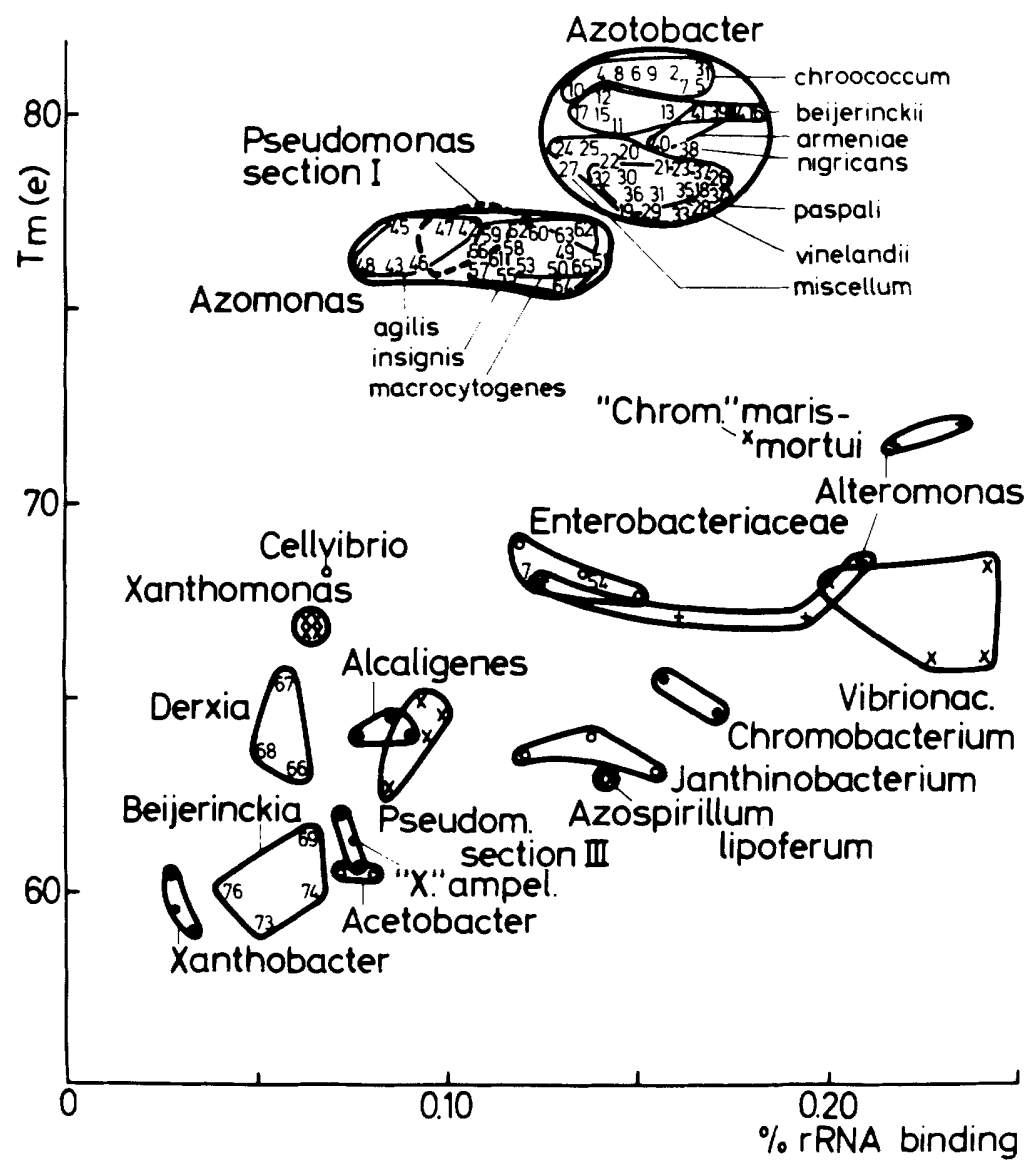

FIG. 2. Similarity map of hybrids between the $23 S{ }^{14} \mathrm{C}$-labeled rRNA fraction of Azotobacter chroococcum NCIB 8002 and the DNAs from a variety of bacteria. $T_{m(e)}$ and percent rRNA binding were as defined in the text. The positions of the organisms belonging to the family Azotobacteriaceae of Bergey's Manual, 8th ed. (13), are indicated by their sequence numbers (Table 1); the positions of the other strains are indicated by symbols $(\times,+, \bigcirc$, and $\bigcirc)$. Strains belonging phenotypically to the same taxon are surrounded by a closed line. These areas locate the taxa on the map; their shapes and dimensions are limited by the number of strains used, and the line is not the ultimate border.

the rRNA cistrons of these organisms to those of Azotobacter and Azomonas was confirmed by reverse hybridizations with labeled rRNA from Pseudomonas fluorescens ATCC 13525 (Table 2).

The Xanthomonas species were close together on the rRNA similarity map, with a $T_{m(e)}$ of $67^{\circ} \mathrm{C}$ and $0.065 \%$ binding, except for the Xanthomonas ampelina strains, which had a $T_{m(e)}$ of 60.5 to $62^{\circ} \mathrm{C}$. Reverse hybridizations with reference rRNA from Xanthomonas campestris NCPPB 528 have shown that the rRNA cistrons of "Xanthomonas" ampelina strains are quite different from those of authentic Xanthomonas species (P. De Vos and J. De Ley, manuscript in preparation).

The $T_{m(e)}$ of the DNA-rRNA hybrid of "Chromobacterium" maris-mortui ATCC 17059 was $71.5^{\circ} \mathrm{C}$. As described previously (19), DNArRNA hybridizations have shown that this strain does not belong in either Chromobacterium or Janthinobacterium. From our results we can conclude that there is a remote relationship with Azotobacter and Pseudomonas section I (13), although ATCC 17059 does not belong in either of these taxa.

Representative strains of the Enterobacteriaceae were grouped at 67.5 to $69^{\circ} \mathrm{C}$ and 0.12 to $0.15 \%$ rRNA binding, whereas strains of the $\mathrm{Vi}$ brionaceae were grouped at 66 to $68.5^{\circ} \mathrm{C}$ and 0.20 to $0.24 \%$ rRNA binding; Cellvibrio vulgaris NCIB 8633 was at about the same distance $\left(T_{m(e)}\right.$ of $68^{\circ} \mathrm{C}$ and $0.07 \%$ rRNA binding). The Alteromonas species were heterogeneous; Alteromonas haloplanktis and Alteromonas macleodii had $T_{m(e)}$ values of 67 to $68.5^{\circ} \mathrm{C}$, whereas 
Alteromonas vaga and Alteromonas communis had $T_{m(e)}$ values of 71.5 and $72^{\circ} \mathrm{C}$, respectively.

Several taxa were located on the rRNA similarity map between $T_{m(e)}$ values of 59 and $65^{\circ} \mathrm{C}$; these included Chromobacterium, Janthinobacterium, the authentic Alcaligenes strains, Pseudomonas strains of section III in Bergey's Manual (13), Derxia, Beijerinckia, Azospirillum, Acetobacter, Xanthobacter autotrophicus, Microcyclus, and "Xanthomonas" ampelina. A $T_{m(e)}$ of $65^{\circ} \mathrm{C}$ seems to be the lower limit for significant taxonomic conclusions (19, 23; J. De Ley et al., manuscript in preparation).
Similarity of Azomonas rRNA cistrons. Hybridizations were also performed between the DNAs of all of our Azomonas strains and reference $\left[{ }^{14} \mathrm{C}\right] \mathrm{rRNA}$ from Azomonas insignis WR 30 and Azomonas agilis NCIB 8636. DNAs of some Azotobacter strains were also included. The results are shown in Table 3 . Obviously, all of these nitrogen-fixing bacteria are closely related. Nevertheless, the rRNA cistrons of $A z o$ monas agilis, Azomonas insignis, and Azomonas macrocytogenes differ as much from each other as from the RNA cistrons of azotobacters.

Similarity of Beijerinckia rRNA cistrons.

TABLE 3. Properties of the hybrids between DNAs from Azomonas and Azotobacter strains and ${ }^{14} \mathrm{C}$-labeled rRNA's from Azomonas agilis NCIB 8636, Azomonas insignis WR 30, and Azotobacter paspali $8 A$

\begin{tabular}{|c|c|c|c|c|c|c|c|}
\hline \multirow{3}{*}{ Species used for DNA prepn } & \multirow{3}{*}{$\begin{array}{l}\text { Strain } \\
\text { no. }\end{array}$} & \multicolumn{6}{|c|}{ Hybridization with $\left[{ }^{14} \mathrm{C}\right] \mathrm{rRNA}$ from: } \\
\hline & & \multicolumn{2}{|c|}{$\begin{array}{c}\text { Azomonas agilis } \\
\text { NCIB } 8636\end{array}$} & \multicolumn{2}{|c|}{$\begin{array}{c}\text { Azomonas insignis } \\
\text { WR } 30\end{array}$} & \multicolumn{2}{|c|}{$\begin{array}{c}\text { Azotobacter paspali } \\
8 \mathrm{~A}\end{array}$} \\
\hline & & $\begin{array}{l}T_{m(e)} \\
\left({ }^{\circ} \mathrm{C}\right)\end{array}$ & $\begin{array}{c}\text { \% rRNA } \\
\text { Binding }\end{array}$ & $\begin{array}{l}T_{m(e)} \\
\left({ }^{\circ} \mathrm{C}\right)\end{array}$ & $\begin{array}{l}\% \text { rRNA } \\
\text { Binding }\end{array}$ & $\begin{array}{l}T_{m(e)} \\
\left({ }^{\circ} \mathrm{C}\right)\end{array}$ & $\begin{array}{l}\% \text { rRNA } \\
\text { Binding }\end{array}$ \\
\hline Azomonas agilis & NCIB 8636 & 79 & 0.164 & 76.5 & 0.102 & & \\
\hline Azomonas agilis & NCIB 8637 & 79 & 0.153 & 76.5 & 0.104 & 76 & 0.078 \\
\hline Azomonas agilis & NCIB 8638 & 79 & 0.162 & 76 & 0.104 & & \\
\hline Azomonas agilis & DSM 375 & 78 & 0.132 & 76.5 & 0.112 & & \\
\hline Azomonas agilis & DSM 89 & 78 & 0.160 & 75.5 & 0.114 & & \\
\hline Azomonas agilis & SS4 & 78 & 0.149 & 76 & 0.115 & & \\
\hline Azomonas agilis & WR 54 & 78.5 & 0.134 & 77 & 0.102 & & \\
\hline Azomonas macrocytogenes & NCIB 9128 & 76.5 & 0.118 & 76.5 & 0.109 & 77 & 0.096 \\
\hline Azomonas macrocytogenes & NCIB 9129 & 75.5 & 0.112 & 77 & 0.101 & & \\
\hline Azomonas macrocytogenes & NCIB 8700 & 76.5 & 0.148 & 76.5 & 0.112 & & \\
\hline Azomonas macrocytogenes & NCIB 8701 & 76.5 & 0.123 & 76.5 & 0.121 & 76.5 & 0.101 \\
\hline Azomonas macrocytogenes & NCIB 8702 & 76 & 0.133 & 77 & 0.138 & & \\
\hline Azomonas insignis & WR 30 & 76.5 & 0.124 & 80.5 & 0.139 & 76.5 & 0.099 \\
\hline Azomonas insignis & WR 12 & 76 & 0.123 & 80 & 0.142 & & \\
\hline Azomonas insignis & WR 29 & 76 & 0.120 & 80.5 & 0.136 & & \\
\hline Azomonas insignis & WR 31 & 75.5 & 0.132 & 80 & 0.143 & & \\
\hline Azomonas insignis & WR 56 & 75.5 & 0.120 & 80 & 0.126 & & \\
\hline Azomonas insignis & WR 59 & 76 & 0.136 & 80.5 & 0.159 & & \\
\hline Azomonas insignis & WR 60 & 76 & 0.134 & 80.5 & 0.164 & & \\
\hline Azomonas insignis & WR 61 & 75 & 0.139 & 78 & 0.159 & & \\
\hline Azomonas insignis & WR 62 & 75.5 & 0.131 & 79.5 & 0.162 & & \\
\hline Azomonas insignis & Tchan C & 76 & 0.123 & 80.5 & 0.138 & & \\
\hline Azomonas insignis & Tchan D & 76 & 0.118 & 80.5 & 0.122 & & \\
\hline Azotobacter chroococcum & NCIB 8515 & 76.5 & 0.137 & 76.5 & 0.134 & & \\
\hline Azotobacter chroococcum & DSM 328 & 76 & 0.136 & 76.5 & 0.150 & 78 & 0.104 \\
\hline Azotobacter beijerinckii & DSM 282 & 76 & 0.138 & 76 & 0.152 & & \\
\hline Azotobacter beijerinckii & NCIB 9067 & & & & & 77.5 & 0.109 \\
\hline Azotobacter beijerinckii & NCIB 9126 & & & & & 78 & 0.098 \\
\hline Azotobacter vinelandii & NCIB 8660 & 75 & 0.142 & 75 & 0.144 & & \\
\hline Azotobacter vinelandii & NCIB 9068 & & & & & 81 & 0.123 \\
\hline Azotobacter vinelandii & DSM 86 & & & & & 81.5 & 0.114 \\
\hline Azotobacter vinelandii & DSM 366 & & & & & 81 & 0.123 \\
\hline Azotobacter vinelandii & DSM 382 & & & & & 81 & 0.110 \\
\hline Azotobacter vinelandii & DSM 389 & & & & & 81.5 & 0.103 \\
\hline Azotobacter paspali & Döbereiner 8A & & & & & 81.5 & 0.149 \\
\hline Azotobacter paspali & Döbereiner 23A & 76 & 0.149 & 75 & 0.167 & 81.5 & 0.140 \\
\hline Azotobacter paspali & DSM 88 & & & & & 81.5 & 0.167 \\
\hline Azotobacter paspali & DSM 376 & & & & & 81.5 & 0.139 \\
\hline Azotobacter paspali & DSM 383 & & & & & 81.5 & 0.132 \\
\hline Azotobacter paspali & DSM 391 & & & & & 81.5 & 0.139 \\
\hline Azotobacter armeniae & WR 136 & 75 & 0.148 & 75.5 & 0.154 & & \\
\hline Azotobacter armeniae & WR 138 & & & & & 78.5 & 0.103 \\
\hline Azotobacter armeniae & WR 128 & & & & & 79 & 0.124 \\
\hline "Azomonas insignis" & ATCC 12523 & 68.5 & 0.126 & 69.5 & 0.130 & & \\
\hline
\end{tabular}


The rRNA similarity map of $B$. indica NCIB 8712 is shown in Fig. 3 . The $T_{m(e)}$ values of the rRNA cistrons of Beijerinckia strains were rather similar to each other $\left(75\right.$ to $\left.78^{\circ} \mathrm{C}\right)$, but the percent rRNA binding was heterogeneous. The $B$. indica strains were very similar, with $T_{m(e)}$ values of 77 to $78^{\circ} \mathrm{C}$ and $0.3 \%$ binding, except for the homologous duplex with $0.52 \%$ binding. The homologous reaction was performed several times with separate DNA preparations and separate DNA filters, always resulting in the same high percent rRNA binding. The $T_{m(e)}$ values of Beijerinckia lacticogenes NCIB 8846 and Beijerinckia fluminensis (both $75.5^{\circ} \mathrm{C}$ ) differed only slightly from those of $B$. indica strains. Beijerinckia mobilis LMD 50.27 was at the same $T_{m(e)}$ level $\left(75^{\circ} \mathrm{C}\right)$ but differed clearly from the other Beijerinckia strains by its low percent rRNA binding $(0.137 \%)$. This hybridization was repeated with separate strain LMD 50.27 DNA preparations and separate DNA filters; the same low percent rRNA binding was found in each case.

Several taxa had $T_{m(e)}$ values between 68 and $72^{\circ} \mathrm{C}$ and percent rRNA binding between 0.03 and 0.07 ; these included Rhodopseudomonas palustris, Rhodopseudomonas capsulata, Rhodopseudomonas sphaeroides, Rhodopseudomonas acidophila, Spirillum itersonii, Xanthobacter autotrophicus, and the misnamed " $M y$ cobacterium" flavum, "Agrobacterium aggregatum" (23), "Pseudomonas" azotocolligans, and "Pseudomonas" diminuta. Another group of taxa was located close to these strains, with $T_{m(e)}$ values from 66 to $68^{\circ} \mathrm{C}$; these included Agrobacterium, Acetobacter, Gluconobacter, Zymomonas, Paracoccus, Azospirillum, and the misnamed "Agrobacterium gelatinovorum," "Agrobacterium luteum," "Azotomonas insolita," Azotomonas sp. ATCC 12210, and "Chromobacterium folium" (23). These results agree very well with the inverse hybridizations between Beijerinckia and Agrobacterium reported previously (23).

Azotobacter and Azomonas strains grouped together, with $T_{m(e)}$ values of 58 to $62^{\circ} \mathrm{C}$, whereas Derxia gummosa NCIB 9064 had a $T_{m(e)}$ of $55^{\circ} \mathrm{C}$. The considerable differences between the rRNA cistrons of Beijerinckia and Azotobacter-Azomonas are obvious from both rRNA similarity

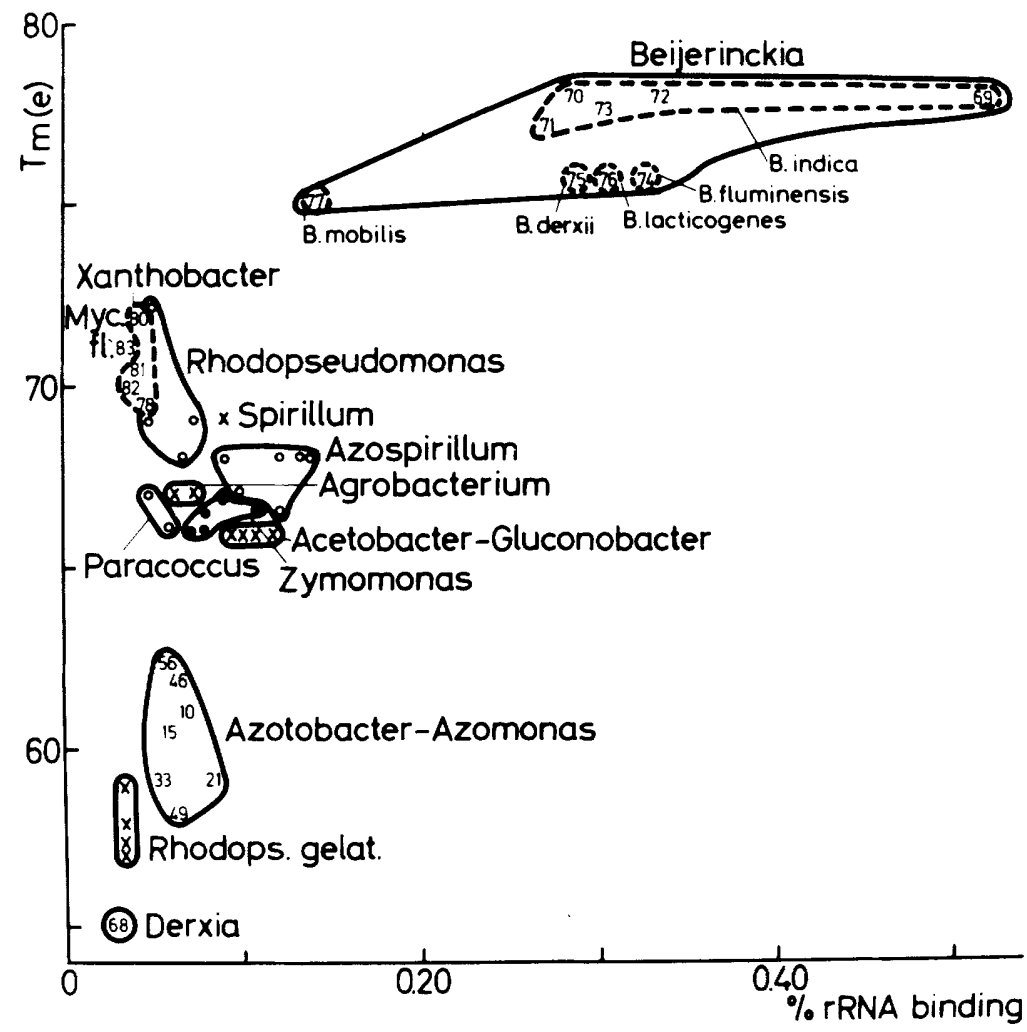

FIG. 3. Similarity map of hybrids between the $16 \mathrm{~S}{ }^{14} \mathrm{C}$-labeled rRNA fraction of B. indica NCIB 8712 and the DNAs from a variety of bacteria. For additional explanation, see legend to Fig. 2. 
maps (Fig. 2 and 3). The Rhodopseudomonas gelatinosa strains grouped together, with $T_{m(e)}$ values of 57 to $59^{\circ} \mathrm{C}$.

Similarity of Derxia rRNA cistrons. The rRNA cistrons of Derxia are quite different from those of Beijerinckia, Azotobacter, and Azomonas. The hybrids of $D$. gummosa DNA with rRNA of Azotobacter chroococcum NCIB 8002 had the same $T_{m(e)}$ values as the hybrids of strains of Alcaligenes, Chromobacterium, Janthinobacterium (19), and Pseudomonas section III of Bergey's Manual (Table 1). Therefore, hybridizations were performed between the DNA of $D$. gummosa and reference $\left[{ }^{14} \mathrm{C}\right] \mathrm{rRNA}$ 's of these taxa (Table 2). The results proved that Derxia is a member of this group of taxa but has a separate position among them ( $T_{m(e)}$, approximately $70^{\circ} \mathrm{C}$ ).

Similarity of Azospirillum rRNA cistrons. The results of the hybridizations with $\left[{ }^{14} \mathrm{C}\right] \mathrm{rRNA}$ from Azospirillum brasilense ATCC 29145 are summarized in Table 1 . The rRNA cistrons of all Azospirillum strains were very similar $\left(T_{m(e)}\right.$ values between 80 and $\left.82.5^{\circ} \mathrm{C}\right)$. Spirillum polymorphum NCIB 9072 and S. itersonii subsp. vulgatum NCIB 9071 had $T_{m(e)}$ values of 71.5 and $72.5^{\circ} \mathrm{C}$, respectively. Representatives of Paracoccus, Agrobacterium, Acetobacter, Gluconobacter, Beijerinckia, Xanthobacter autotrophicus, and "Mycobacterium" flavum had $T_{m(e)}$ values between 65 and $69^{\circ} \mathrm{C}$, showing that Azospirillum belongs in the rRNA superfamily of these taxa.

\section{DISCUSSION}

The taxonomic relationships among numerous genera and subgenera of gram-negative bacteria, involving hundreds of bacterial species, are being investigated in our laboratory by DNA-rRNA hybridizations (17, 19, 23; De Ley et al., manuscript in preparation). With this method we have been able to classify these taxa into several rRNA superfamilies. The first rRNA superfamily contains the Enterobacteriaceae and the $\mathrm{Vi}$ brionaceae; the second superfamily consists of Pseudomonas section I of Bergey's Manual (13), Xanthomonas, Aplanobacter, and several other taxa; the third rRNA superfamily consists of Chromobacterium, Janthinobacterium (19), Pseudomonas sections II and III (13), the authentic Alcaligenes strains, and several other taxa; and the fourth rRNA superfamily consists mainly of taxa connected with the phytosphere, i.e. Rhizobium, Agrobacterium, Phyllobacterium, Zymomonas, Acetobacter, Gluconobacter, and several other taxa. An important point for the present discussion is that there is a distinct correlation between rRNA similarities, ex- pressed as $T_{m(e),}$ and the overall phenotypic similarities of the organisms $(19,23$; De Ley et al., manuscript in preparation).

It is very striking that 10 strains of Azotobacter chroococcum, 7 strains of Azotobacter beijerinckii, 9 strains of Azotobacter vinelandii, 1 strain of Azotobacter miscellum (very likely identical with Azotobacter vinelandii [15]), 1 strain of Azotobacter nigricans, and 10 strains of Azotobacter paspali have rRNA cistrons which are almost identical (Tables 1 and 3 ) and are thus located very close together on the rRNA similarity map (Fig. 2). It is very encouraging to note that all of the cyst-forming organisms, which are phenotypically very similar, have very similar rRNA cistrons. Our results confirm that the genus Azotobacter, as described in Bergey's Manual, 8th ed. (13), is a real biological taxon and not a taxonomic artifact. Strains WR 136, WR 138 and WR 139 were isolated from soil in Armenia and were originally classified as Azotobacter agilis subsp. armeniae (34). In a numerical analysis of the Azotobacteriaceae, J. P. Thompson (Ph.D. thesis, University of Queensland, Queensland, Australia, 1975) classified Azotobacter nigricans and Azotobacter armeniae as separate species in Azotobacter and designated Azotobacter miscellum a subjective synonym of Azotobacter vinelandii. The same author proposed that a new genus be established for Azotobacter paspali. However, the latter proposal is opposed by our observations on rRNA similarities, which very strongly suggest that Azotobacter paspali is a normal member of the genus Azotobacter.

A total of 7 strains of Azomonas agilis, 5 strains of Azomonas macrocytogenes, and 11 strains of Azomonas insignis all fall in the same area on the rRNA similarity map. It should be noted that Azomonas insignis ATCC 12523 is misidentified. We received two subcultures of this strain from the American Type Culture Collection, and both gave the same results, as follows. The $T_{m(e)}$ of $68^{\circ} \mathrm{C}$ is far outside the range of the $T_{m(e)}$ values of authentic Azomonas insignis strains. The $\mathrm{G}+\mathrm{C}$ content of the DNA of ATCC 12523 is 43.4 instead of 55 to $58 \mathrm{~mol} \%$. On our growth media, this organism was not motile, contrary to the findings of Derx (22), who described the motility of Azomonas insig. nis as very characteristic. The actual taxonomic position of ATCC 12523 is unknown. De Ley and Park (18) discovered that the DNA base composition of Azomonas agilis (51 to $53 \mathrm{~mol} \%$ $\mathrm{G}+\mathrm{C}$ ) is quite different from that of Azomonas macrocytogenes and Azomonas insignis (55 to $59 \mathrm{~mol} \% \mathrm{G}+\mathrm{C}$ ). Therefore, these authors suggested locating Azomonas agilis in a separate genus as Azotococcus agilis and locating Azo- 
monas insignis and Azomonas macrocytogenes in Azomonas. In Bergey's Manual, 8th ed. (13), all three species are included in the genus $A z o$ monas. We reexamined this problem by hybridizing DNAs from organisms in this group with $\left[{ }^{14} \mathrm{C}\right]$ rRNA's from Azomonas insignis WR 30 and Azomonas agilis NCIB 8636 (Table 3). The rRNA cistrons of Azomonas macrocytogenes, Azomonas insignis, and Azomonas agilis differ as much from each other as they do from the rRNA cistrons of azotobacters $\left(T_{m(e)}\right.$ of the DNA-rRNA hybrids, from 75 to $76.5^{\circ} \mathrm{C}$ ). The relationship between these four taxa can be expressed nomenclaturally in several ways. One solution would be to create three separate genera, one each for Azomonas agilis, Azomonas macrocytogenes, and Azomonas insignis; this might be the most logical solution but it is certainly not the most practical solution for the moment. However, pending further research on phenotypic analysis and genome comparisons, we prefer temporarily to retain the three species in the genus Azomonas. This genus is more heterogeneous $(\mathrm{G}+\mathrm{C}$ content, from 52 to 59 mol\%; $T_{m(e)}$ of the intrageneric DNA-rRNA hybrids from 75 to $80.5^{\circ} \mathrm{C}$ ) than is Azotobacter (63 to $67.5 \mathrm{~mol} \% \mathrm{G}+\mathrm{C}$; intrageneric $T_{m(e)}$, from 77.5 to $81^{\circ} \mathrm{C}$ ).

Tables 1 and 3 and Fig. 2 show that there is a close similarity in $T_{m(e)}$ values among the rRNA cistrons of azotobacters, the three species of Azomonas, and the species of Pseudomonas section I (13). In addition, these five taxa are equidistant from each other at a $T_{m(e)}$ of about $76^{\circ} \mathrm{C}$. We concluded from these rRNA similarities that the taxa Azotobacter, Azomonas, and Pseudomonas section I belong in the same rRNA superfamily. Our conclusion on the close genetic relatedness between Pseudomonas section I and Azotobacter is emphasized by a comparison of the structure of another gene product. Ambler (1) found close similarities between the amino acid sequences of cytochrome c-551 of five Pseudomonas species from section I and cytochrome c-551 of Azotobacter vinelandii. The sequence differences between the cytochromes from the Pseudomonas strains were in the range of 20 to $40 \%$, and the cytochrome of Azotobacter vinelandii differed by the same amount from the Pseudomonas cytochromes. Ambler (1) writes, "It is interesting to note that by this single genetic criterion $A$. vinelandii is as good a Pseudomonas as any of the others." The full importance of this observation has been underestimated up to now. However, in conjunction with our results on rRNA cistron similarities, both arguments are powerful evidence that Pseudomonas, Azotobacter, and Azomonas are close branches of the same phylogenetic tree.
The similarity in $T_{m(e)}$ values between the rRNA cistrons of Azotobacter and Azomonas and the rRNA cistrons of pseudomonads other than the pseudomonads in section $I$ is much smaller ( $T_{m(e)}, 62$ to $\left.64^{\circ} \mathrm{C}\right)$. The explanation is that the present genus Pseudomonas is extremely heterogeneous (36) and consists very likely of at least two genera and a number of misnamed strains ( De Vos and De Ley, manuscript in preparation).

The genus Alteromonas is heterogeneous (Table 1 and Fig. 2). Alteromonas vaga and Alteromonas communis are located in the same rRNA superfamily as Azotobacter and Azomonas at $T_{m(e)}$ values of 71.5 to $72^{\circ} \mathrm{C}$. Alteromonas haloplanktis and Alteromonas macleodii are located in the vicinity of the Enterobacteriaceae and the Vibrionaceae, with $T_{m(e)}$ values of 67 to $68.5^{\circ} \mathrm{C}$. The rRNA heterogeneity of Alteromonas agrees very well with the results of a numerical analysis of the phenotypic features of a diversity of aerobic marine bacteria. Alteromonas vaga and Alteromonas communis grouped together at $72 \%$ phenotypic similarity in one group of taxa, whereas Alteromonas hal. oplanktis and Alteromonas macleodii clustered at $72 \%$ similarity with a second group of taxa; both groups linked at $40 \%$ phenotypic similarity (5).

The genus Beijerinckia is much more heterogeneous than Azotobacter and Azomonas. Although the $T_{m(e)}$ values of all of the strains used are limited within a $3^{\circ} \mathrm{C}$ range, the percent rRNA binding varies from $0.14 \%$ for $B$. mobilis LMD 50.27 to $0.52 \%$ for the reference strain $B$. indica NCIB 8712 (Table 1 and Fig. 3). The rRNA features of the remaining strains of $B$. indica, $B$. lacticogenes, $B$. fluminensis, and $B e i$ jerinckia derxii are very similar, with $T_{m(e)}$ values of $76.75 \pm 1.25^{\circ} \mathrm{C}$ and rRNA binding of 0.30 $\pm 0.04 \%$. In Bergy's Manual (13), Azotobacter lacticogenes was identified with $B$. indica, whereas $B$. fluminensis, $B$. derxii, and $B$. mobilis were recognized as separate species. Since $B$. lacticogenes is located in the same region as $B$. fluminensis and $B$. derxii on the rRNA similarity map (Fig. 3), further conclusions on the intrageneric taxonomic relationships of Beijerinckia can only be drawn when more phenotypic and genome comparisons become available. The extreme position of $B$. mobilis LMD 50.27 on the rRNA similarity map suggests that it may be a rather exceptional member of the genus. This is corroborated by the unusual phenotypic features of the species $B$. mobilis summarized in Table 7.9 Bergey's Manual (13). On the rRNA similarity map (Fig. 3 ) there are no genera in the immediate vicinity of Beijerinckia, which suggests that this genus has a separate phylogenetic 
position; it is indeed phenotypically easily distinguished from almost all other genera of bacteria. From Table 1 and Fig. 3 , it is at once obvious that rRNA cistrons of Beijerinckia are not the closest relatives of those of Azotobacter, Azomonas, and Derxia. Beijerinckia belongs in an rRNA superfamily with Agrobacterium, Rhizobium (23), Acetobacter, Gluconobacter, Zy. momonas (Gillis and De Ley, manuscript in preparation), and other taxa (this paper). The phenotypic similarity among Agrobacterium, Rhizobium, and Beijerinckia has been determined (28). De Ley et al. (16) clustered these three genera on the basis of their average interand intra group phenotypic similarities. When strains of these genera were clustered on the basis of their average $T_{m(e)}$ values, it is very striking that a similar dendrogram was obtained (Fig. 4). The rRNA cistrons of Beijerinckia most closely resemble those of Rhodopseudomonas palustris, $R$. sphaeroides, $R$. capsulata, Spirillum itersonii subsp. vulgatum, Xanthobacter autotrophicus, and the misnamed "Mycobacterium" flavum, "Pseudomonas" azotocolligans, "Pseudomonas" diminuta, and "Agrobacterium" aggregatum (23).

Schlegel and co-workers $(6,27,40,45)$ isolated yellow-pigmented, nitrogen-fixing hydrogen bacteria with several properties characteristic of coryneform bacteria and initially classified them as Corynebacterium autotrophicum (6). These organisms do not utilize carbohydrates, except gluconate and sometimes fructose, which are catabolized by way of the Entner-Doudoroff pathway. They grow well on organic acids. Recently, Schlegel and co-workers (47) concluded from cell wall analysis and physiological data that this organism is not a coryneform, and they renamed it Xanthobacter autotrophicus (48). This is in excellent agreement with our results. Observations in our laboratory (J. De Smedt and J. De Ley, manuscript in preparation) have shown that the rRNA cistrons of true coryneforms are quite different from those of all gramnegative bacteria tested. It is obvious from the position of Xanthobacter on the rRNA similarity map (Table 1 and Fig. 3 ) that it belongs in our fourth rRNA superfamily of gram-negative taxa (see above), in which the presence of the Entner-Doudoroff pathway is a common feature (33).

The yellow-pigmented, nitrogen-fixing " $M y$ cobacterium" flavum 301 was isolated by Fedorov and Kalininskaya (26) from Russian turf

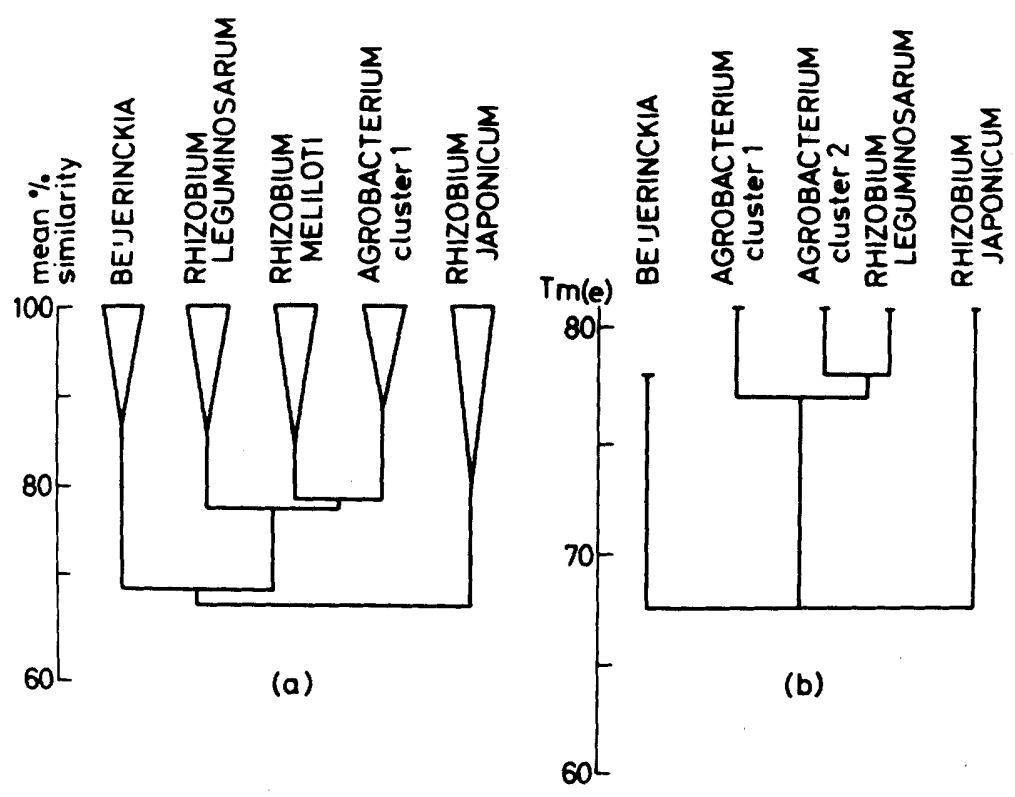

FIG. 4. Comparison of the phenetic similarity and the similarity of the rRNA cistrons of Agrobacterium, Rhizobium, and Beijerinckia. (a) Phenetic similarity as calculated by De Ley et al. (16) from the data of Graham (28), involving 100 features of 8 strains of Beijerinckia, 32 strains of Rhizobium leguminosarum, 25 strains of Rhizobium meliloti, 27 strains of Rhizobium japonicum, and 18 strains of Agrobacterium tumefaciens and Agrobacterium radiobacter. Each group is represented by an inverted triangle, the bottom tip of which indicates the intragroup mean percent similarity. (b) Linkage of Agrobacterium, Rhizobium, and Beijerinckia according to the $T_{m(e)}$ values of their DNA-rRNA hybrids. $T_{m(e)}$ is expressed in degrees centigrade. The $T_{m(e)}$ values are summarized from De Smedt and De Ley (23) and from the present paper. 
podzol soil. This organism does not utilize carbohydrates but grows on ethanol and organic acids. Biggins and Postgate (8) examined a number of features of this strain. Its exact taxonomic position is unknown. "Mycobacterium" flavum 301 has the same position as Xanthobacter autotrophicus on the rRNA similarity map of Fig. 3 . This finding points to a possible close relationship between these two taxa. It also shows that "Mycobacterium" flavum 301 does not belong in Mycobacterium, which is completely outside our fourth rRNA superfamily (De Smedt and De Ley, manuscript in preparation).

$R$. palustris, $R$. sphaeroides, $R$. capsulata, and $R$. acidophila are located in the same region as Xanthobacter autotrophicus on the rRNA similarity map compared with $B$. indica NCIB 8712 (Fig. 3). Upon close inspection, some phenotypic similarities between the two genera are evident. Van Niel (46) described the cell morphology of $R$. palustris in older cultures as "strikingly reminiscent of Corynebacterium and Mycobacterium species."Likewise, $R$. capsulata and $R$. sphaeroides have irregular cell shapes (46). Cell morphology was one of the main reasons why Schlegel and co-workers (6) originally classified their hydrogen bacterium as a corynebacterium. Both Xanthobacter and Rhodopseudomonas fix nitrogen, use molecular hydrogen as an electron donor, possess hydrogenase and catalase, produce carotenoid pigments, have the same range of $\mathrm{G}+\mathrm{C}$ content (between 65 and $70 \mathrm{~mol} \%$ ), use many organic acids as substrate, assimilate few or no carbohydrates, and possess the Entner-Doudoroff pathway. The position of $R$. gelatinosa is exceptional. We tested four strains of this species. On the rRNA similarity map of $B$. indica (Fig. 3), they are all located at a $T_{m(e)}$ of 57 to $59^{\circ} \mathrm{C}$, quite out of the range of the other Rhodopseudomonas species. From hybridizations with other reference rRNA's, we know that these strains are not related to the Enterobacteriaceae, the Vibrionaceae, the Rhizobiaceae, Chromobacterium, Janthinobacterium, the acetic acid bacteria, and many other taxa (M. Gillis P. De Vos, J. De Smedt, and J. De Ley, manuscript in preparation). Hybridizations with ${ }^{14} \mathrm{C}$-labeled rRNA from Pseudomonas acidovorans ATCC 15668 have shown that the rRNA cistrons of the $R$. gelatinosa strains have closer similarity $\left(T_{m(e)}\right.$, from 74.5 to $\left.75.5^{\circ} \mathrm{C}\right)$ to the rRNA cistrons of Pseudomonas acidovorans (De Vos and De Ley, manuscript in preparation). Obviously, $R$. gelatinosa is generically misnamed and belongs in a different rRNA superfamily. Its exceptional taxonomic position is in excellent agreement with phenotypic information (N. Pfennig, personal communication) and with amino acid sequence data (2). Cytochrome $c_{2}$ of authentic rhodopseudomonads is most similar to cytochrome $c_{550}$ of Paracoccus denitrificans. R. gelatinosa cytochrome $c_{2}$, how ever, more closely resembles cytochrome $c_{551}$ of Pseudomonas. Our data suggest that $R$. gelatinosa should be moved to another genus. The probable kinship between Paracoccus denitrificans and authentic rhodopseudomonads is confirmed by DNA-rRNA hybridizations; they are located in the same region on the rRNA similarity map and belong in our fourth rRNA superfamily (Fig. 3). Our results show that there are unexpected distinct generic similarities between authentic Rhodopseudomonas strains and our fourth rRNA superfamily (Agrobacterium, Rhizobium, Acetobacter, Gluconobacter, Zymomonas, Beijerinckia, Azospirillum, etc.). This tends to upset the widespread view that phototrophic bacteria constitute a separate phylogenetic branch, entirely different from the ordinary chemoorganotrophic bacteria and most closely related to the primitive bacteria from the Precambriam period.

"Pseudomonas" azotocolligans was described by Anderson (3) as a nitrogen-fixing, polarly flagellated organism. However, Hill and Postgate (30) found no nitrogen fixation for "Pseudomonas" azotocolligans NCIB 9391, and De Ley (15) showed that the same strain was peritrichous. On the basis of flagellation, this organism was misidentified. The results of the DNA-rRNA hybridizations agree perfectly with the latter conclusion.

"Pseudomonas" diminuta is phenotypically (4) and on the basis of DNA homology (37) and rRNA homology (38) quite different from the other Pseudomonas groups. This organism does not utilize carbohydrates, only some alcohols and organic acids. Physiologically it most closely resembles Gluconobacter (4). The rRNA cistrons show remote similarity to those of Acetobacter and Gluconobacter (Gillis and De Ley manuscript in preparation). Our results agree with these findings.

Previously, we have shown that "Agrobacterium" aggregatum does not belong in Agrobac. terium (23). This organism is located on the rRNA similarity map of $B$. indica NCIB 8712 at a $T_{m(e)}$ of $72^{\circ} \mathrm{C}$. Two other misidentified organisms ("Agrobacterium" gelatinovorum and "Agrobacterium" luteum) are located in the same rRNA superfamily.

Azospirillum belongs in the same rRNA superfamily as Beijerinckia (Fig. 3). The rRNA cistrons of Azospirillum lipoferum and Azospirillum brasilense are very similar (Table 1$)$. The interspecies DNA homology in this genus was 30 
to $50 \%$ (44). A similar situation was described previously for Agrobacaterium cluster I (23); organisms with $45 \%$ or more DNA homology have almost identical rRNA cistrons. The closest relatives of Azospirillum now known are $S$. itersonii subsp. vulgatum and S. polymorphum. Although these organisms belong in one rRNA group, the inclusion of the nitrogen-fixing azospirilla in a separate genus (44) seems justified; with respect to their rRNA cistrons, they differ as much from the authentic spirilla as Azotobacter differs from Alteromonas communis and Alteromonas vaga. The Azospirillum strains and some Spirillum strains investigated constitute a separate branch in our fourth rRNA superfamily.

Derxia is the fourth genus included in the family Azotobacteriaceae in Bergey's Manual, 8 th ed. (13). Its rRNA cistrons are quite different from those of Azotobacter, Azomonas, and Beijerinckia. From the hybridizations between the DNAs from three D. gummosa strains and the ${ }^{14} \mathrm{C}$-labeled rRNA's from a great variety of other organisms (Tables 1 and 2), it is quite obvious that the Derxia rRNA cistrons most closely resemble those of Pseudomonas acidovorans, Pseudomonas solanacearum, Chromobacterium violaceum, Janthinobacterium lividum, and Alcaligenes faecalis. These taxa, together with a few others, constitute our third rRNA superfamily, which consists of gram-negative rods which are usually 0.5 to 1 by 1 to $4 \mu \mathrm{m}$, do not have resting stages, have 57 to $72 \mathrm{~mol} \%$ $\mathrm{G}+\mathrm{C}$, are chemo-organotrophic, exhibit respiratory metabolism, and occur in soil and water (19).

Biological fixation of molecular nitrogen can be performed by a great variety of procaryotic microorganisms $(39,42)$. Most of the aerobic, free-living, nitrogen-fixing bacteria have been assembled in the family Azotobacteriaceae. In the 6th (10) and 7th (11) editions of Bergey's Manual, this family contained only one genus, Azotobacter, and three species, Azotobacter chroococcum, Azotobacter agilis, and Azotobacter indicus. In the 8th edition of Bergey's Manual (13), there are four genera in the family Azotobacteriaceae: Azotobacter, Azomonas, Beijerinckia, Derxia. There appear to be two main reasons why these genera are maintained in one family: (i) they all fix nitrogen, and (ii) three of the four genera (Azotobacter, Azomonas, and Beijerinckia) are based on species which had been placed in the genus Azotobacter (11). No other specific fundamental features except Gram negativity, strict aerobiosis, and chemo-organotrophy support the classification of these four genera into one family. These gen- era are phenotypically very heterogeneous in cell size and shape, cyst formation, type of flagellation, lipid inclusion, manner of growth, $\mathrm{G}+\mathrm{C}$ composition of DNA, etc. $(19,27,29,30$, 45). Previous experience in our laboratory has shown that organisms which belong to a wellestablished, phenotypic family, such as the $R h i$ zobiaceae (23), the Enterobacteriaceae, or the Vibrionaceae (De Ley, Tytgat, and De Smedt, manuscript in preparation), form DNA-rRNA hybrids with a $T_{m(e)}$ of at least $68^{\circ} \mathrm{C}$. Derxia, Beijerinckia, Xanthobacter, and Azospirillum are all at a $T_{m(e)}$ below $66^{\circ} \mathrm{C}$ versus Azotobacter. They can thus not belong in the same family as Azotobacter. The free-living, nitrogen-fixing bacteria occur in three rRNA superfamilies. These results induce us to conclude either that the present family Azotobacteriaceae does not exist as a biological unit or that it should be limited to the genera Azotobacter and Azomonas.

\section{ACKNOWLEDGMENTS}

J.D.L. and J.D.S. thank the Fonds voor Kollektief en Fundamenteel Onderzoek for research and personnel grants and for a scholarship, respectively. M.B. is indebted to the Instituut tot Aanmoediging van het Wetenschappelijk Onderzoek in Nijverheid en Landbouw for a scholarship.

We are indebted to all who kindly provided strains. We thank H. G. Schlegel for providing freeze-dried cells of Xanthobacter autotrophicus and "Mycobacterium" flavum.

\section{REPRINT REQUESTS}

Address reprint requests to: Prof. J. De Ley, Laboratory of Microbiology, Rijksuniversiteit, K. L. Ledeganckstraat 35, B9000 Gent, Belgium.

\section{LITERATURE CITED}

1. Ambler, R. P. 1973. Bacterial cytochromes c and molecular evolution. Syst. Zool. 22:554-565.

2. Ambler, R. P. 1978. Amino acid sequences and bacterial phylogeny, p. 311-322. In H. Matsubara and T. Yamanaka (ed.), Evolution of protein molecules. Japan Scientific Societies Press, Center for Academic Publications, Tokyo, Japan.

3. Anderson, G. R. 1955. Nitrogen fixation by Pseudomonas-like soil bacteria. J. Bacteriol.70:129-133.

4. Ballard, R. W., M. Doudoroff, and R. Y. Stanier. 1968. Taxonomy of the aerobic pseudomonads: Pseudomonas diminuta and P. vesiculare. J. Gen. Microbiol. 53:349361.

5. Baumann, L., P. Baumann, M. Mandel, and R. D. Allen. 1972. Taxonomy of aerobic marine eubacteria. J. Bacteriol. 110:402-429.

6. Baumgarten, J., M. Reh, and H. G. Schlegel. 1974. Taxonomic studies on some gram-positive coryneform hydrogen bacteria. Arch. Mikrobiol. 100:207-217.

7. Beijerinck, M. W. 1901 . Ueber oligonitrophile Mikroben. Zentralbl. Bakteriol. Parasitenkd. Infektionskr. Hyg. Abt. 2 7:561-582.

8. Biggins, D. R., and J. R. Postgate. 1969. Nitrogen fixation by cultures and cell-free extracts of Mycobac. terium flauum 301. J. Gen. Microbiol. 56:181-193.

9. Bousfield, I. J., and S. D. Graham (ed.). 1975. The national collection of industrial bacteria catalogue of 
strains. Her Majesty's Stationery Office, London.

10. Breed, R. S., E. G. D. Murray, and A. P. Hitchens (ed.). 1948. Bergey's manual of determinative bacteriology, 6th ed. The Williams \& Wilkins Co., Baltimore.

11. Breed, R. S., E. G. D. Murray, and N. R. Smith (ed.). 1957. Bergey's manual of determinative bacteriology, 7th ed. The Williams \& Wilkins Co., Baltimore.

12. Brenner, D. J. 1973. Deoxyribonucleic acid reassociation in the taxonomy of enteric bacteria. Int. J. Syst. Bacteriol 23:298-307.

13. Buchanan, R. E., and N. E. Gibbons (ed.). 1974. Bergey's manual of determinative bacteriology, 8 th ed. The Williams \& Wilkins Co., Baltimore.

14. De Ley, J. 1967. The quick approximation of DNA base composition from absorbancy ratios. Antonie van Leeuwenhoek J. Microbiol. Serol. 33:203-208.

15. De Ley, J. 1968. DNA base composition and classification of some more free-living nitrogen-fixing bacteria. Antonie van Leeuwenhoek J. Microbiol. Serol. 34:66-70.

16. De Ley, J., M. Bernaerts, A. Rassel, and J. Guilmot. 1966. Approach to an improved taxonomy of the genus Agrobacterium. J. Gen. Microbiol. 43:7-17.

17. De Ley, J., and J. De Smedt. 1975. Improvements of the membrane filter method for DNA: rRNA hybridizations. Antonie van Leeuwenhoek J. Microbiol. Serol. 41:287-307.

18. De Ley, J., and I. W. Park. 1966. Molecular biological taxonomy of some free-living nitrogen-fixing bacteria. Antonie van Leeuwenhoek J. Microbiol. Serol. 32:616.

19. De Ley, J., P. Segers, and M. Gillis. 1978. Intra- and intergeneric similarities of Chromobacterium and Jan thinobacterium ribosomal ribonucleic acid cistrons. Int. J. Syst. Bacteriol. 28:154-168.

20. De Ley, J., R. Tytgat, J. De Smedt, and M. Michiels. 1973. Thermal stability of DNA:DNA hybrids within the genus Agrobacterium. J. Gen. Microbiol. 78:241252.

21. Derx, H. G. 1950. Beijerinckia, a new genus of nitrogenfixing bacteria occurring in tropical soils. Proc. K. Ned. Akad. Wet. Ser. C 53:140-147.

22. Derx, H. G. 1951. Azotobacter insigne spec. nov., fixateur d'azote à flagellation polaire. Proc. K. Ned. Akad. Wet. Ser. C 54:342-350.

23. De Smedt, J., and J De Ley. 1977. Intra- and intergeneric similarities of Agrobacterium ribosomal ribonucleic acid cistrons. Int. J. Syst. Bacteriol. 27:222-240.

24. Döbereiner, J. 1977. Biological nitrogen fixation in tropical grasses-possibilities for partial replacement of mineral N fertilizers. Ambio 6:175-177.

25. Dubnau, D., I. Smith, P. Morrell, and J. Marmur. 1965. Gene conservation in Bacillus species. 1. Conserved genetic and nucleic acid base sequence homologies. Proc. Natl. Acad. Sci. U.S.A. 54:491-498.

26. Fedorov, M. V., and T. A. Kalininskaya. 1961. A new species of a nitrogen fixing Mycobacterium and its physiological peculiarities. Mikrobiologiya 30:9-14.

27. Gogotov, J. N., and H. G. Schlegel. 1974. N.-fixation by chemoautotrophic hydrogen bacteria. Arch. Mikrobiol. 97:359-362.

28. Graham, P. H. 1964. The application of computer techniques to the taxonomy of the root-nodule bacteria of legumes. J. Gen. Microbiol. 35:511-517.

29. Hilger, F. 1965. Etudes sur la systématique du genre Beijerinckia Derx. Ann. Inst. Pasteur Paris 109:406423.

30. Hill, S., and J. R. Postgate. 1969. Failure of putative nitrogen-fixing bacteria to fix nitrogen. J. Gen. Micro- biol. 58:277-285.

31. Jensen, H. L. 1954. The Azotobacteriaceae. Bacteriol. Rev. 18:195-214.

32. Jensen, H. L., E. J. Petersen, P. K. De, and R. Bhattacharya. 1960. A new nitrogen-fixing bacterium: Derxia gummosa nov. gen. nov. spec. Arch. Mikrobiol. 36:182-195.

33. Kersters, K., and J. De Ley. 1968. The occurrence of the Entner-Doudoroff pathway in bacteria. Antonie van Leeuwenhoek J. Microbiol. Serol. 34:393-408.

34. Kirakosyan, A. V., and Z. S. Melkonyan. 1964. Nouvelles variétés d'Azotobacter agile dans les sols d'Arménie Akad. Nauk. Arm. SSR, Izvest., Biol. Nauki 17:33-42. (in Russian)

35. Marmur, J. 1961. A procedure for the isolation of deoxyribonucleic acid from micro-organisms. J. Mol. Biol. 3: 208-218.

36. Moore, R. L., and B. J. McCarthy, 1967. Comparative study of ribosomal ribonucleic acid cistrons in Enterobacteriaceae and Myxobacteria. J. Bacteriol. 94:10661074.

37. Palleroni, N. J., R. W. Ballard, E. Ralston, and M. Doudoroff. 1972. Deoxyribonucleic acid homologies among some Pseudomonas species. J. Bacteriol. 110:111.

38. Palleroni, N. J., R. Kunisawa, R. Contopoulou, and M. Doudoroff. 1973. Nucleic acid homologies in the genus Pseudomonas. Int. J. Syst. Bacteriol. 23:333-339.

39. Quispel, A. (ed.). 1974. The biology of nitrogen fixation. North Holland Publishing Co., Amsterdam.

40. Schneider, K., V. Rudolph, and H. G. Schlegel. 1973. Description and physiological characterization of a coryneform hydrogen bacterium, strain $14 \mathrm{~g}$. Arch. Mikrobiol. 93:179-193.

41. Starkey, R. L., and P. K. De. 1939. A new species of Azotobacter. Soil Sci. 47:329-343.

42. Stewart, W. D. D. (ed.). 1975. Nitrogen fixation by free living microorganisms. Cambridge University Press, Cambridge, England.

43. Takahashi, H., H. Saito, and Y. Ikeda. 1967. Species specificity of the ribosomal RNA cistrons in bacteria. Biochim. Biophys. Acta 134:124-133.

44. Tarrand, J. J., N. R. Krieg, and J. Döbereiner. 1978. A taxonomic study of the Spirillum lipoferum group, with descriptions of a new genus, Azospirillum gen. nov. and two species, Azospirillum lipoferum (Beijerinck) comb. nov. and Azospirillum brasilense sp. nov. Can. J. Microbiol. 24:967-980

45. Tunail, N., and H. G. Schlegel. 1974. A new coryneform hydrogen bacterium: Corynebacterium autotrophicum strain 7C. I. Characterization of the wild type strain. Arch. Mikrobiol. 100:341-350.

46. Van Niel, C. B. 1944. The culture, general physiology, morphology and classification of the non-sulfur purple and brown bacteria. Bacteriol. Rev. 8:1-118.

47. Walther-Mauruschat, A., M. Aragno, F. Mayer, and H. G. Schlegel. 1977. Micromorphology of gram-negative hydrogen bacteria. II. Cell envelope, membranes and cytoplasmic inclusions. Arch. Mikrobiol. 114:101110

48. Wiegel, J., D. Wilke, J. Baumgarten, R. Opitz, and H. G. Schlegel. 1978. Transfer of the nitrogen-fixing hydrogen bacterium Corynebacterium autotrophicum Baumgarten et al. to Xanthobacter gen. nov. Int. J. Syst. Bacteriol. 28:573-581.

49. Winogradsky, S. 1938. Etudes sur la microbiologie de sol et des eaux. Sur la morphologie et l'oecologie des Azotobacter. Ann. Inst. Past. Paris 60:351-400. 